\title{
The two CO-dehydrogenases of Thermococcus sp. AM4
}

Martino Benvenuti ${ }^{+a}$, Marta Meneghello ${ }^{+a}$, Chloé Guendon ${ }^{a}$, Aurore Jacq-Bailly ${ }^{a}$, Jae-hun Jeoung $^{\mathrm{b}}$, Holger Dobbek ${ }^{\mathrm{b}}$, Christophe Léger ${ }^{\mathrm{a}}$, Vincent Fourmond ${ }^{\mathrm{a}^{*}}$ and Sébastien Dementin ${ }^{\mathrm{a}^{*}}$ ${ }^{a}$ Aix-Marseille Université, CNRS, BIP UMR 7281, 31 chemin J. Aiguier, CS70071 F-13402 Marseille cedex 20 (France)

${ }^{b}$ Institut für Biologie, Strukturbiologie/Biochemie, Humboldt-Universität zu Berlin, Unter den Linden 6, 10099 Berlin (Germany)

'These authors contributed equally

*Correspondence: vincent.fourmond@imm.cnrs.fr, dementin@imm.cnrs.fr

\section{Abstract}

Ni-containing CO-dehydrogenases (CODHs) allow some microorganisms to couple ATP synthesis to $\mathrm{CO}$ oxidation, or to use either $\mathrm{CO}$ or $\mathrm{CO}_{2}$ as a source of carbon. The recent detailed characterizations of some of them has evidenced a great diversity in terms of catalytic properties and resistance to $\mathrm{O}_{2}$. In an effort to increase the number of available CODHs, we have heterologously produced in Desulfovibrio fructosovorans, purified and characterized the two CooS-type CODHs (CooS1 and CooS2) from the hyperthermophilic archaeon Thermococcus sp. AM4 (Tc). We have also crystallized CooS2, which is coupled in vivo to a hydrogenase. CooS1 and CooS2 are homodimers, and harbour five metalloclusters: two $\mathrm{NiFe}_{4} \mathrm{~S}_{4} \mathrm{C}$ clusters, two [4Fe4S] B clusters and one interfacial [4Fe4S] D cluster. We show that both are dependent on a maturase, $\mathrm{CooC} 1$ or $\mathrm{CooC2}$, which is interchangeable. The homologous protein CooC3 does not allow Ni insertion in either CooS. The two CODHs from Tc have similar properties: they can both oxidize and produce $\mathrm{CO}$. The Michaelis constants $\left(K_{m}\right)$ are in the microM range for $\mathrm{CO}$ and in the $\mathrm{mM}$ range $(\mathrm{CODH} 1)$ or above $(\mathrm{CODH} 2)$ for $\mathrm{CO}_{2}$. Product inhibition is observed only for $\mathrm{CO}_{2}$ reduction, consistent with $\mathrm{CO}_{2}$ binding being much weaker than $\mathrm{CO}$ binding. The two enzymes are rather $\mathrm{O}_{2}$ sensitive (similarly to $\mathrm{CODH}$ II from Carboxydothermus hydrogenoformans), and react more slowly with $\mathrm{O}_{2}$ than any other $\mathrm{CODH}$ for which these data are available.

Keywords: Ni-containing carbon monoxide dehydrogenase; protein film voltammetry; crystal structure; metalloenzyme; metalloenzyme maturation 


\section{Introduction}

Some representatives of the archaeal genus Thermococcus oxidize one-carbon compounds (carbon monoxide and/or formate) to gain energy for hydrogenogenic growth [1]. The genomes of these organisms all contain gene clusters coding for three modules: a CO or formate dehydrogenase ( $\mathrm{CODH}$ or $\mathrm{Fdh}$, respectively), a $\mathrm{H}_{2}$-evolving proton translocating membrane-bound hydrogenase $(\mathrm{MBH})$, and a $\mathrm{Na}^{+} / \mathrm{H}^{+}$antiporter. The mechanism of energy conversion from formate through such a bioenergetic system has been described in the case of Thermococcus onnurineus. The coupling of formate oxidation and $\mathrm{H}_{2}$ production leads to proton translocation across the membrane, which drives the establishment of a $\mathrm{Na}^{+}$gradient involving a $\mathrm{Na}^{+} / \mathrm{H}^{+}$antiporter; this gradient drives ATP synthesis through a $\mathrm{Na}^{+}-\mathrm{ATP}$ synthase [2,3]. Although not experimentally confirmed, the hypothesis that a similar mechanism occurs during CO-driven hydrogenogenic growth with $\mathrm{CODH}$ in place of Fdh is supported by the following observations: 1) the genomes of the Thermococcus species that grow on CO contain a threemodule gene cluster coding for a $\mathrm{CODH}$, a $\mathrm{MBH}$ and a $\mathrm{Na}^{+} / \mathrm{H}^{+}$antiporter [1] and 2) the transfer of the trimodular cluster from $T$. onnurineus into Pyrococcus furiosus renders this organism capable of CO-driven hydrogenogenic growth [4]. In some cases, in the presence of elemental sulfur, $\mathrm{CO}$ or formate oxidation is coupled to the production of $\mathrm{H}_{2} \mathrm{~S}$ (sulfidogenic growth) but the genetic and biochemical bases of this bioenergetic process are unknown.

Hyperthermophilic Thermococcus sp. AM4 (TAM4), isolated from a deep sea hydrothermal vent [5], is capable of CO-driven hydrogenogenic and sulfidogenic growth, but does not grow on formate [1]. This organism has two genes encoding for CODH: TAM4_582 and TAM4_1067, which we rename herein cooS1 and cooS2, respectively.

The gene cooS1 is probably responsible for $\mathrm{CO}$ oxidation necessary for lithoheterotrophic growth on CO plus sulfur [6]. Indeed, cooS1 is part of a gene cluster (figure $1 \mathrm{~A})$ that is also found in $T$. gammatolerans EJ3, the phylogenetically closest Thermococcalesspecies, which is only able to perform CO-driven sulfidogenic growth. This cluster contains three genes encoding for putative ferredoxins (TAM4_766, TAM4_648 and TAM4_719). TAM4_594, annotated as a FAD-dependent pyridine nucleotide-disulfide oxidoreductase on the KEGG website (https://www.genome.jp/kegg/), encodes for a putative flavin containing oxidoreductase of unknown function. TAM4_809, TAM4_575 and TAM4_768 are respectively annotated as hydrogenase 3 maturation protease, iron-molybdenum cofactorbinding protein, and malic acid transport protein. Whether this cluster is involved in COdependent sulfidogenic growth has not been investigated yet. A gene encoding a putative CODH accessory nickel-insertion protein CooC (TAM4_754) is located upstream of this cluster andoriented in the opposite direction (figure 1A). We rename this gene cooC1. 
A

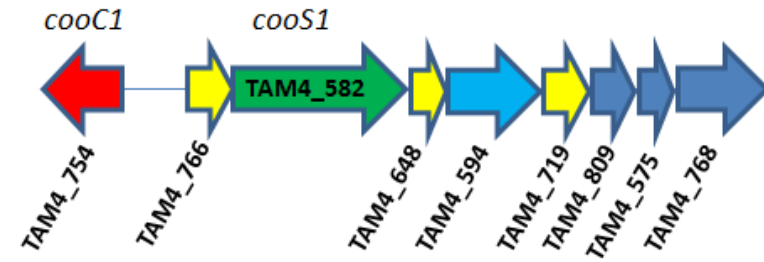

B

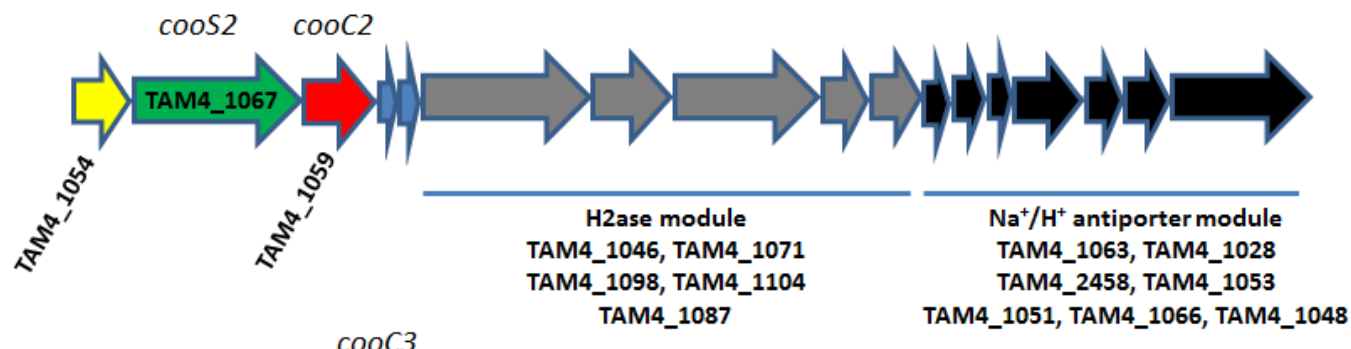

$\mathrm{C}$

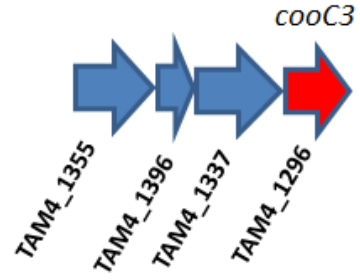

Figure 1: Organization of the gene clusters containing coos1 and coos2. A) Gene cluster containing cooS1 (TAM4_582). TAM4_594 (light blue) encodes for an annotated FADdependent pyridine nucleotide-disulfide oxidoreductase of unknown function which is the putative redox partner of CooS1. B) Gene cluster containing cooS2 (TAM4_1067). This cluster contains the bioenergetic three-module system composed of a $\mathrm{CODH}$, a membranebound hydrogenase and a putative $\mathrm{Na}^{+} / \mathrm{H}^{+}$antiporter. C) Gene cluster containing the third annotated cooC copy (cooC3). TAM4_1355, TAM4_1396 and TAM4_1337 encode, respectively, for a putative cobalt/zinc/cadmium cation efflux pump protein, a putative nickel responsive regulator NikR, and a putative secreted cellulase. The $\mathrm{CODH}$ encoding genes are in green, the CooC encoding genes are in red, the putative ferredoxin encoding genes are in yellow.

As expected for a Thermococcus species capable of a CO-driven hydrogenogenic growth, the genome of TAM4 contains a putative trimodular $\mathrm{CODH}-\mathrm{MBH}-\mathrm{Na}^{+} / \mathrm{H}^{+}$antiporter gene cluster (figure 1B) [6]. The CODH encoding gene is cooS2. This cluster is homologous to that found in other Thermococcus species [7]. We rename cooC2 the gene TAM4_1059, which encodes for a putative accessory nickel-insertion protein CooC.

The genes cooS1 and cooS2 encode for Ni-containing CooS-type CODHs, whose archetypes are the CODH from Rhodospirillum rubrum $(R r)$ and CODH II from Carboxydothermus hydrogenoformans (Ch) [8]. These enzymes are intertwined homodimers containing five metalloclusters of three different types [9-11]. Each monomer contains a $C$ cluster, which is the Ni-Fe-S containing active site where $\mathrm{CO} / \mathrm{CO}_{2}$ interconversion occurs. The $\mathrm{C}$ cluster is a [Ni-3Fe-4S] cubane connected through a bridging sulfide to a unique Fe ion. At the interface between the two monomers, at the surface of the protein, the $D$ cluster, an iron-sulfur 
cluster coordinated by two cysteines of each monomer, is the putative entry/exit point of electrons that are transferred from the $\mathrm{C}$ cluster to the enzyme redox partner, and vice versa. The nature of the $\mathrm{D}$ cluster is determined by the protein sequence at the $N$-terminus: it is a [4Fe4S] cluster when the two coordinating cysteines are in a $\mathrm{C}-\mathrm{X}_{7}-\mathrm{C}$ motif, or a [2Fe-2S] cluster when the motif is $\mathrm{C}-\mathrm{X}_{2}-\mathrm{C}$ [12]. Last, two classical [4Fe-4S] clusters (called B clusters), buried in each monomer, probably mediate electron transfer between the $D$ and $C$ clusters (see also figure $2 \mathrm{~A}$ for the overall structure of CODHs).

Under normal growth conditions, the insertion of $\mathrm{Ni}$ into the $\mathrm{C}$ clusters depends on the accessory ATPase CooC, but in some cases the lack of $c 00 \mathrm{C}$ can be alleviated by an excess of $\mathrm{Ni}$ in the growth medium [13-15]. Besides the two coo C copies found in each of the two CODH clusters, TAM4 contains a third cooC copy (which we rename cooC3) located in a different part of the genome (TAM4_1296). According to the KEGG website, this gene is probably part of a cluster whose expression is dependent on divalent cations. Indeed, upstream from TAM4_1296, three genes (TAM4_1355, TAM4_1396 and TAM4_1337) encode for a putative cobalt/zinc/cadmium cation efflux pump protein, a putative nickel responsive regulator NikR, and a putative secreted cellulase, respectively (figure $1 \mathrm{C}$ ). We recently determined that the product of TAM4_1337 is indeed a cellulase, which loses its thermostability upon incubation with divalent cations such as $\mathrm{Ni}^{2+}$ and $\mathrm{Co}^{2+}$ (unpublished data). We therefore hypothesized that CooC3 is an alternative accessory protein likely superseding $\mathrm{CooC} 1$ and/or $\mathrm{CooC} 2$ in response to $\mathrm{Ni}$ excess or depletion.

In this paper, we present the first purification and characterization of the two CODHs from TAM4: TC CODH 1 and TC CODH 2. We investigate the effects of the co-expression of the maturases $\mathrm{CooC} 1, \mathrm{CooC} 2$ or CooC3 on the activity and metal content of the enzymes. We determine the structure of a not fully-mature form of CooS2, and we compare the catalytic properties of the two fully-mature CODHs: catalytic bias, Michaelis constants, product inhibition, and reactivity with $\mathrm{O}_{2}$.

\section{Materials and Methods}

\subsection{Strains}

E. coli strain DH5a (F-, endA1, hsdR17(rK - mK +), supE44, thi-1, $\lambda-$, recA1, gyrA96, relA1, $\Delta$ (argF- lacZYA)U169, $\varphi 80$ dlacZ $\Delta \mathrm{M} 15)$ was used as a host for the construction of recombinant plasmids. The cultures were routinely grown at $37^{\circ} \mathrm{C}$ in Luria-Bertani (LB) medium containing $100 \mu \mathrm{g} / \mathrm{mL}$ ampicillin or $20 \mu \mathrm{g} / \mathrm{mL}$ gentamicin when needed. Desulfovibrio fructosovorans (Df) strain MR400 (hyn::npt $\triangle$ hynABC) carrying a deletion in the [NiFe] hydrogenase operon [16] was grown anaerobically for 5 days at $37^{\circ} \mathrm{C}$ in fructose/sulfate medium as previously described [17]. $50 \mu \mathrm{g} / \mathrm{mL}$ kanamycin was present routinely, and $20 \mu \mathrm{g} / \mathrm{mL}$ gentamicin was added only when cells harbored the expression vectors.

\subsection{Plasmids construction for the production of Tc CODH 1 and 2 in Desulfovibrio fructosovorans}

We designed plasmids to express Tc coos1 or Tc cooS2 in the absence or presence of their corresponding $\mathrm{cooC}_{\mathrm{C}}$ maturation gene. The expression is under the control of the strong 
promoter of the Df [NiFe] hydrogenase operon by using the pBGF4 plasmid, a shuttle vector of the pBM family, carrying a gentamicin resistance gene as described in [18]. For PCR amplifications we used Thermococcus sp. AM4 genomic DNA, kindly provided by Dr Philippe Oger (Laboratoire Microbiologie, Adaptation et Pathogénie, UMR 5240, CNRS/INRA/Université Lyon 1, France).

For Tc CODH 1, Tc cooS1 (TAM4_582) was amplified by PCR using the primers pair 1 and 2 (see Supporting Table S5). The 5' extremity of the PCR product (called PCR product 1) contains a RBS functional in $D$. fructosovorans, the start codon and the sequence encoding streptag-II. PCR product 1 was cloned into pBGF4 without ligase using the Hot Fusion polymerase as described in [19]. First, to add overlapping sequences with the vector to be joined at the 5' and 3' ends, PCR product 1 was used as a template for PCR amplification using the primers pair 3 and 4 (see supporting Table S5). The resulting PCR product 2 and Agel/Kpnldigested pBGF4 were mixed with T5 exonuclease and Hot Fusion polymerase according to the protocol described in [19]. The resulting plasmid was called pBG_TcCooS1. Tc cooC1 (TAM4_754) was amplified by PCR using the primers pair 5 and 6 (Table S5). The 5' extremity of the PCR product (called PCR product 3) contains a RBS functional in D. fructosovorans and the start codon. Given that attempts to clone PCR product 3 in pBG_TcCooS1 without ligase failed, we decided to clone it using the conventional method with restriction enzymes and ligase. PCR product 3 was then flanked by Kpnl sites by PCR amplification using the primers pair 7 and 8 (Table S5). The resulting PCR product 4 was ligated into Kpnl-digested pBG_TcCooS1 to yield pBG_TcCooSC1.

For Tc CODH 2, Tc cooS2 (TAM4_1067) was amplified by PCR using the primers pair 9 and 10 (Table S5). The 5' extremity of the PCR product contains the Agel site, the RBS, the start codon and the sequence encoding streptag-II. This PCR product was cloned into the blunt pJET1.2 vector (PCR Cloning Kit, Thermo Fisher Scientific) and the resulting plasmid was used as a template for site directed mutagenesis to remove the Agel site within Tc cooS2 using the primers pair 11 and 12 (Table S5). For this purpose, a silent mutation G332G was introduced. The Agel-Kpnl fragment of the mutated plasmid was cloned into Agel/Kpnl-digested pBGF4 to yield the plasmid pBG_TcCooS2. Tc cooC2 (TAM4_1059) was amplified using the primers pair 13 and 14 (Table S5). The 5' extremity of the PCR product contains a Kpnl site, a RBS functional in $D$. fructosovorans and the start codon. It was ligated into Kpnl-digested pBG_TcCooS2 to yield the plasmid pBG_TcCooSC2.

To assess the potential involvement of $c 00 \mathrm{C} 3$ in $\mathrm{Ni}$ insertion into $\mathrm{CODH} 1$ and $\mathrm{CODH} 2$, TAM4_1059 was cloned into pBG_TcCooS1 and pBG_TcCooS2. TAM4_1059 was amplified by PCR with the primers pair 15 and 16 (Table S5). The 5' end of the PCR product contains a Kpnl site, a RBS functional in $D$. fructosovorans and the start codon. This Kpnl-digested PCR product was inserted into Kpnl-digested pBG_TcCooS1 and pBG_TcCooS2 to yield pBG_TcCooS1C3 and pBG_TcCooS2C3.

To study the potential effect of $\mathrm{cooC}_{1}$ and $\mathrm{cooC} 2$ on Ni-insertion into $\mathrm{CODH} 1$ and $\mathrm{CODH} 2$, we cloned the Kpnl-digested TC cooC1 and TC cooC2 PCR products described above in Kpnl-digested pBG_TcCooS2 and pBG_TcCooS1, respectively. The resulting plasmids are called pBG_TcCooS2C1 and pBG_TcCooS1C2.

The recombinant plasmids were verified by sequencing and introduced into the $D f$ strain 
MR 400 by electrotransformation. The proteins were purified as described in [18] except that cells were disrupted in the glovebox by sonication. The gels are available in SI figure 10.

\subsection{Activity assays}

We measured the $\mathrm{CO}$ oxidation and $\mathrm{CO}_{2}$ reduction activity in a glove box (Jacomex, filled with $\mathrm{N}_{2}, \mathrm{O}_{2}<4 \mathrm{ppm}$ ) using a Varian Cary 50 spectrophotometer with a probe of $1 \mathrm{~cm}$ optical length. The $\mathrm{CO}$ oxidation activity was monitored at $37^{\circ} \mathrm{C}$ by following the reduction of methyl viologen (MV) over time at $604 \mathrm{~nm}\left(\varepsilon=13.6 \mathrm{mM}^{-1} \mathrm{~cm}^{-1}\right)$ in a plastic cuvette. Before recording the $\mathrm{CO}$ oxidation activity, $\mathrm{Tc} \mathrm{CODHs}(+/-\mathrm{CoOC})$ were diluted to a final concentration of $0.44 \mu \mathrm{M}$ in $0.1 \mathrm{M}$ Tris- $\mathrm{HCl}, \mathrm{pH} 8$ (untreated enzyme). To assess the possible activation of the enzymes under reducing conditions in the presence of $\mathrm{Ni}$ or not, Tc CODHs (+/- CooC) were diluted to a final concentration of $0.44 \mu \mathrm{M}$ in $0.1 \mathrm{M}$ Tris- $\mathrm{HCl}, \mathrm{pH} 8$ solution containing either 2.4 $\mathrm{mM} \mathrm{NiCl} 2$ and $1.2 \mathrm{mM}$ sodium dithionite (NaDT) or $2.4 \mathrm{mM} \mathrm{NiCl}, 1.2 \mathrm{mM}$ tris(2carboxyethyl)phosphine (TCEP) and $4 \mathrm{mM} \mathrm{Na}_{2} \mathrm{~S}$. The untreated or treated enzymes were incubated for 1,15 , and 90 minutes or 24 hour before recording the CO oxidation activity. To start the reaction, $5 \mu \mathrm{L}$ of the untreated or treated enzymes were injected in a magnetic-stirred 1 $\mathrm{mL}$ solution containing $0.1 \mathrm{M}$ Tris- $\mathrm{HCl}(\mathrm{pH}$ 8), $2.4 \mathrm{mM} \mathrm{MV}, 10 \mu \mathrm{M} \mathrm{NaDT}$ and $25 \mu \mathrm{M} \mathrm{CO}(25 \mu \mathrm{L}$ of a CO-saturated solution were injected just before the addition of the enzyme).

The $\mathrm{CO}_{2}$ reduction activity was monitored at $25^{\circ} \mathrm{C}$ by following the formation of carboxyhemoglobin over time at $433 \mathrm{~nm}\left(\varepsilon=185 \mathrm{mM}^{-1} \mathrm{~cm}^{-1}\right)$. To start the reaction, $2.5 \mu \mathrm{g}$ of untreated enzyme was injected in a magnetic-stirred $1 \mathrm{~mL}$ solution containing $0.1 \mathrm{M} \mathrm{Tris} / \mathrm{HCl}(\mathrm{pH} 8)$ or 0.1 M CHES (pH 6), $0.1 \mathrm{mM}$ EDTA, $10 \mathrm{mM} \mathrm{NaHCO}_{3}\left(\mathrm{CO}_{2}\right.$ source), $0.25 \mathrm{mM} \mathrm{MV}, 2 \mathrm{mM} \mathrm{NaDT}$ and $0.2 \mathrm{mg}$ hemoglobin.

\subsection{Elemental analysis}

We determined the nickel and iron contents of the protein samples $(500 \mu \mathrm{L}$ of $5-10 \mu \mathrm{M}$ protein solution) by ICP optical emission spectrometry (ICP-OES) using an iCAP 6000 spectrometer (ThermoFisher Scientific).

\subsection{Electrochemical experiments}

Electroactive films of Tc CODHs were prepared by simply depositing $0.5 \mu \mathrm{L}$ of enzyme stock solution (10 - $30 \mu \mathrm{M}$ in $0.1 \mathrm{M}$ Tris-HCl buffer, $\mathrm{pH}$ 8) onto a rotating disc pyrolytic graphite edge electrode (RDE, $2.5 \mathrm{~mm}$ diameter), as described in [20]. All electrochemical experiments were performed in a standard three-electrode cell filled with $2 \mathrm{~mL}$ of the buffer solution of choice, with the RDE graphite electrode as working electrode, a platinum wire as counter electrode, and a saturated calomel electrode (SCE, from Radiometer Analytical, France) as reference placed in a distinct compartment filled with $0.1 \mathrm{M} \mathrm{NaCl}$. All electrode potentials are reported with respect to the SHE. The electrodes were connected to an Autolab PGSTAT128N potentiostat (Metrohm, The Netherlands), controlled through the software GPES, and the working electrode was also connected to an Autolab RDE 2 electrode rotator (Metrohm, The Netherlands). All experiments were carried out by rotating the working electrode at rotation rates of 4000-5000 rpm to avoid depletion of the substrate at the electrode surface, inside a Jacomex glove box filled with $\mathrm{N}_{2}\left(\mathrm{O}_{2}<4 \mathrm{ppm}\right)$. 


\subsubsection{Catalytic bias}

These experiments were performed in a $\mathrm{pH} 6$ buffer solution containing $0.2 \mathrm{M}$ MES and $0.1 \mathrm{M} \mathrm{NaCl}$, through cyclic voltammetry at $20 \mathrm{mV} / \mathrm{s}$, by submitting films of CODH to four consecutive injections of either $1 \mathrm{M}$ carbonate solution or CO-saturated solution. We first injected $10 \mathrm{mM}$ carbonate (to give $7 \mathrm{mM} \mathrm{CO}_{2}$ ) at the cycle 0 ; when the $\mathrm{CO}_{2}$ reduction current completely disappeared we injected $0.1 \mathrm{mM} \mathrm{CO}$ at the cycle $n$; then again $10 \mathrm{mM}$ carbonate at the cycle $2 n$, and finally again $0.1 \mathrm{mM} \mathrm{CO}$ at the cycle $3 n$.

\subsubsection{Determination of $K_{m}$ for $\mathrm{CO}$}

We have measured the $K_{m}$ values relative to the substrate $\mathrm{CO}$ by monitoring through chronoamperometry (at $-0.31 \mathrm{~V}$ vs. SHE) the CO oxidation current following injections in the electrochemical cell of aliquots of CO-saturated buffer. Such experiments were performed at $\mathrm{pH}$ 7 in a mixed buffer solution containing $5 \mathrm{mM}$ each of MES, sodium acetate, HEPES, TAPS and CHES, and $0.1 \mathrm{M} \mathrm{NaCl}$. The CO-saturated solution was prepared by bubbling $\mathrm{CO}$ gas for about 40-45 min in a $16 \mathrm{~mL}$ gas-tight Hungate tube filled with $8 \mathrm{~mL}$ of the same $\mathrm{pH} 7 \mathrm{mixed}$ buffer, so that the concentration of $\mathrm{CO}$ dissolved in the buffer was $1 \mathrm{mM}$. Different aliquots of the COsaturated solution (between 50 and $200 \mu \mathrm{L}$ ) were injected in the electrochemical cell through a gas-tight syringe (SGE Analytical Science). The exchange of gas between the electrochemical cell and the atmosphere of the glove box results in an exponential decrease in the concentration of $\mathrm{CO}$ in the cell [21]. We have quantitatively modeled the electrochemical signal by taking into account mass-transport limitations, using the software QSoas [22] (http://qsoas.org) and the method described in [23].

\subsubsection{Determination of $K_{m}$ for $\mathrm{CO}_{2}$}

These experiments were performed through chronoamperometry (at $-0.66 \mathrm{~V}$ vs. SHE) in a $\mathrm{pH} 6$ buffer solution containing $0.2 \mathrm{M} \mathrm{MES}$ and $0.1 \mathrm{M} \mathrm{NaCl}$, through injections of different aliquots of carbonate solution using the following procedure: the electrochemical cell was filled with $1.6 \mathrm{~mL}$ of $\mathrm{pH} 6$ buffer; other $0.4 \mathrm{~mL}$ of the same buffer were placed in a vial and mixed with an aliquot of $1 \mathrm{M} \mathrm{Na}_{2} \mathrm{CO}_{3}$ (between 1 and $20 \mu \mathrm{L}$ ); after $30 \mathrm{~s}$ from mixing the carbonate with the buffer in the vial, such solution was injected in the cell to have a final volume of $2 \mathrm{~mL}$. In this way, the carbonate equilibrates in the $\mathrm{pH} 6$ buffer before being added in the electrochemical cell, becoming $70 \% \mathrm{CO}_{2}$ and $30 \% \mathrm{HCO}_{3}{ }^{-}$, the major species in equilibrium at $\mathrm{pH} 6$ since $\mathrm{pKa}\left(\mathrm{CO}_{2} / \mathrm{HCO}_{3}{ }^{-}\right)=6.4$. Therefore, the solution injected in the cell contained $\mathrm{CO}_{2}$ with a concentration equal to $\sim 70 \%$ of the initial carbonate concentration. Also in this case, the exchange of gas between the cell and the atmosphere of the glove box results in an exponential decrease in the concentration of $\mathrm{CO}_{2}$ in the cell, slower than the decrease of $\mathrm{CO}$. We have quantitatively modeled the electrochemical signal assuming that all the $\mathrm{CO}_{2}$ and hydrated $\mathrm{CO}_{2}$ species stay in permanence at equilibrium, using the software QSoas [22] and Eq. (2), corresponding to the following command:

fit-arb im/ $(1+\mathrm{km} / \mathrm{co} 2)+$ io /with $=\mathrm{co} 2: 1$, exp

For the fits, we have used $\left[\mathrm{CO}_{2}\right]_{0}=70 \%$ of the injected carbonate concentration. 


\subsubsection{Product inhibition}

These experiments were performed in a pH 6 buffer solution containing $0.2 \mathrm{M} \mathrm{MES} \mathrm{and}$ $0.1 \mathrm{M} \mathrm{NaCl}$, through chronoamperometry at $-0.31 \mathrm{~V}$ to study the inhibition of $\mathrm{CO}$ oxidation by $\mathrm{CO}_{2}$, and at $-0.66 \mathrm{~V}$ to study the inhibition of $\mathrm{CO}_{2}$ reduction by $\mathrm{CO}$. All experiments were carried out using a two-injection procedure, injecting first the substrate, and immediately after the inhibitor. For the inhibition of $\mathrm{CO}$ oxidation by $\mathrm{CO}_{2}$, we injected $100 \mu \mathrm{L}$ of CO-saturated buffer and, after $10 \mathrm{~s}$, an aliquot of $1 \mathrm{M}$ carbonate (up to $10 \mu \mathrm{L}$ ) to give $70 \%$ of $\mathrm{CO}_{2}$ after a few seconds. For the inhibition of $\mathrm{CO}_{2}$ reduction by $\mathrm{CO}$, we injected $400 \mu \mathrm{L}$ of buffer $+5 \mu \mathrm{L}$ of $1 \mathrm{M}$ carbonate (already mixed in a vial as described above) and, after $20 \mathrm{~s}$, an aliquot of COsaturated buffer (up to $50 \mu \mathrm{L}$ ). We have quantitatively modeled the electrochemical signal using the software QSoas and Eq. (3), corresponding to the following command:

fit-arb $\mathrm{im} /\left(1+\mathrm{km} / \mathrm{co}^{*}(1+\mathrm{co} / \mathrm{ki})\right)+$ io $/ \mathrm{with}=\mathrm{co} 2: 1$, exp; $\mathrm{co}: 1$, exp

The fits were performed by imposing the values of $K_{m}$ relative to $\mathrm{CO}_{2}$, which were equal to 0.3 $\mathrm{mM}$ in the case of $T c \mathrm{CODH} 1$ (value of $\mathrm{Km}$ previously found), and $17 \mathrm{mM}$ for $T c \mathrm{CODH} 2$ (like in Figure 6).

\subsubsection{Inhibition by $\mathrm{O}_{2}$}

To characterize the reactivity of the enzymes with $\mathrm{O}_{2}$, we have used the method described in ref. [23]: the experiments were performed in a $\mathrm{pH} 7$ mixed buffer through chronoamperometry at $-0.31 \mathrm{~V}$ vs. SHE, by injecting in the cell six consecutive aliquots of $100 \mu \mathrm{L}$ CO-saturated buffer. Injections 1,3 and 5 were preceded by $20 \mathrm{~s}$ poise at $-0.76 \mathrm{~V}$, and an aliquot of $\mathrm{O}_{2}$-saturated (or air-saturated) buffer was injected $10 \mathrm{~s}$ after injection 3 (see Supplementary Figure S7).

\subsection{Crystal structure determination}

\subsubsection{Crystallization}

Crystals of the Ni-free CooS2 were obtained by sitting-drop vapor diffusion under anoxic conditions in an atmosphere of $95 \% \mathrm{~N}_{2} / 5 \% \mathrm{H}_{2}$ inside a glove box (model B; COY Laboratory Products, Inc.). The crystals were grown in a condition containing $0.1 \mathrm{M}$ phosphate/citrate $(\mathrm{pH}$ $4.2)$ and $40 \%(\mathrm{w} / \mathrm{v})$ polyethyleneglycol 300 by mixing of equivalent volumes of reservoir with 15 $\mathrm{mg} / \mathrm{ml}$ protein in $100 \mathrm{mM}$ Tris- $\mathrm{HCl}$ buffer $(\mathrm{pH} 8)$ with $2 \mathrm{mM}$ Na-dithionite. The crystal was flashcooled in liquid $\mathrm{N}_{2}$ with $15 \%(\mathrm{v} / \mathrm{v}) 2 \mathrm{R}, 3 \mathrm{R}$-butanediol as a cryo-protectant.

\subsubsection{Data collection, structure determination and refinement}

Diffraction data were collected at $100 \mathrm{~K}$ on beamline BL 14.1 (BESSY, Berlin, Germany) [24]. Diffraction data were integrated and scaled using XDSAPP [25]. A search model for molecular replacement was generated by Swiss-Model (https://swissmodel.expasy.org/) using the structure of $\mathrm{Ch} \mathrm{CODH}$ II with $48 \%$ sequence identity [14], as a homologous search structure ( PDB ID 3B53). Initial phases were obtained from Patterson search techniques with AutoMR from Phenix [26]. Several cycles of automated model building and refinement were carried out with AutoBuild from Phenix. After iterative manual model building using Coot [27], further refinements were performed using phenix.refine from Phenix. 
Since there was no experimental support for the presence of $\mathrm{Ni}$ or $\mathrm{Fe}$ at the Ni-binding site, we exclusively refined the $\mathrm{C}$ cluster of CooS2 as a Ni-free cluster with three chains in the asu.

Data collection and refinement statistics of the reported structures are given in Table S1. Coordinate and structure factor amplitude have been deposited in the Protein Data Bank under accession number $6 \mathrm{~T} 7 \mathrm{~J}$.

Channels were calculated using MOLEonline (version: Mole 2.5) [28].

All figures of structures in this work were prepared using UCSF Chimera version 1.12 [29].

\section{Results}

\subsection{Nomenclature}

In the first part of the results section, we have used the denomination "CooS1" to refer to the product of the gene coos1 expressed in the absence of any maturase, and the denominations "CooS1+C1", "CooS1+C2", etc. to refer to the product of the gene cooS1 co-expressed with the maturase $\operatorname{cooC} 1$ (or cooC2). The same thing was done in the case of "CooS2". In the second part of the results section, the proteins we have used were the result of the expression of either $\operatorname{cooS} 1$ or cooS2 co-expressed in the presence of their corresponding maturase. We have abbreviated the CooS1+C1, CooS2+C2 notations to simply CODH 1 and CODH 2.

\subsection{Production and characterization of the two Tc CODHs}

For each of the two structural genes encoding for $\mathrm{CODH}, \operatorname{cooS} 1$ and $\operatorname{coos} 2$, we have constructed 8 plasmids, for either expressing the protein alone (decorated with an affinity tag for purification), or co-expressing it with $\mathrm{cooC}_{1}, \mathrm{cooC} 2$ or cooC3. We have produced the corresponding proteins and purified them to homogeneity. We have determined their metal content using ICP-OES, and their $\mathrm{CO}$ oxidation rates in solution assays using oxidized methyl viologen as electron acceptor. The results are presented in table 1. 


\begin{tabular}{|c|c|c|c|c|}
\hline $\begin{array}{l}\text { Enzyme } \\
\text { (number of } \\
\text { analyzed } \\
\text { preparations) }\end{array}$ & $\begin{array}{l}\mathrm{CO} \text { oxidation rate at } \\
\mathrm{pH} 8 \\
\left(\mu \mathrm{mol} \mathrm{min}^{-1} \mathrm{mg}^{-1}\right)\end{array}$ & $\begin{array}{l}\text { Fe } / \text { monomer } \\
\text { (expected = } \\
10)\end{array}$ & $\begin{array}{l}\mathrm{Ni} / \text { monomer } \\
(\text { expected }=1)\end{array}$ & $\begin{array}{l}\text { Ni content } / \mathrm{Fe} \\
\text { content } \\
(\text { expected }=0.1)\end{array}$ \\
\hline $\begin{array}{l}\text { Tc Coos1 } \\
(\mathrm{n}=4)\end{array}$ & $5.5 \pm 1.2$ & $8.4 \pm 1.6$ & $0.16 \pm 0.04$ & 0.019 \\
\hline $\begin{array}{l}T c \operatorname{CooS} 1+C 1 \\
(\mathrm{n}=4)\end{array}$ & $27 \pm 3$ & $8.1 \pm 0.3$ & $0.49 \pm 0.1$ & 0.060 \\
\hline $\begin{array}{l}\text { Tc CooS } 1+C 2 \\
(\mathrm{n}=2)\end{array}$ & $62 \pm 1$ & $8.9 \pm 2.3$ & $0.75 \pm 0.1$ & 0.084 \\
\hline $\begin{array}{l}T c \operatorname{CooS} 1+C 3 \\
(\mathrm{n}=1)\end{array}$ & $6.4 \pm 1.4$ & 7.7 & 0.14 & 0.018 \\
\hline $\begin{array}{l}\text { Tc Coos } 2 \\
(\mathrm{n}=5)\end{array}$ & $10.5 \pm 3.5$ & $6.8 \pm 1.6$ & $0.11 \pm 0.1$ & 0.016 \\
\hline $\begin{array}{l}T c \text { Coos } 2+C 2 \\
(n=5)\end{array}$ & $210 \pm 80$ & $7.7 \pm 1$ & $0.70 \pm 0.2$ & 0.091 \\
\hline $\begin{array}{l}T c \text { CooS } 2+C 1 \\
(\mathrm{n}=2)\end{array}$ & $262 \pm 20$ & $9.8 \pm 3.6$ & $0.91 \pm 0.54$ & 0.093 \\
\hline $\begin{array}{l}T c \operatorname{CooS} 2+C 3 \\
(n=2)\end{array}$ & 12.4 & $9.7 \pm 3.9$ & $0.15 \pm 0.05$ & 0.015 \\
\hline
\end{tabular}

Table 1: $\mathrm{CO}$ oxidation activity at $\mathrm{pH} 8$ (determined from solution assays) and metal content (determined by ICP-OES) for all the possible combinations of co-expression of cooS1 or cooS2 with the three maturases (8 constructions).

The results show that both CooS1 and CooS2 require co-expression with either CooC1 or CooC2 to achieve optimal activity. CooC3 seems to have no effect on the activity of the expressed enzymes, whose activities and nickel contents are comparable with those observed after expression without maturase. While $\mathrm{CooC} 1$ and $\mathrm{CooC} 2$ seem interchangeable, it is remarkable that CooS1 is significantly more active when co-expressed with $\mathrm{CooC} 2$ than with $\mathrm{CooC} 1$. This is probably the result of a better Ni-incorporation into the active site of CooS1, which has 1.4 times more $\mathrm{Ni}$ when produced with $\mathrm{CooC} 2$ than with $\mathrm{CooC} 1$.

We have observed that the enzymes activate to some extent (up to a factor of 2) upon incubation with nickel under reducing conditions (see SI Table S1). However this activation is much less pronounced than in the case of Desulfovibrio vulgaris $(D v) \mathrm{CODH}$, for which activation factors of up to 20 could be measured between the as-prepared enzyme and the enzyme incubated with nickel and dithionite [18]. Therefore, in the case of Tc CODHs we have chosen to functionally characterize the as-prepared enzymes. 


\subsection{Crystal structure of Ni-free CooS2 (expressed without maturase)}

\subsubsection{Overall structure}

We determined the crystal structure of CooS2 produced in the absence of any CooC maturation protein (which we refer to as just "CooS2"). The structure of CooS2 has been refined including reflections to a $d_{\min }$ of $2.34 \AA$ with $R_{\text {work }} / R_{\text {free }}$ of 20.6/25.6 (SI Table S2). The crystal had the orthorhombic space group P $2{ }_{1}{ }_{1} 2$ and contained three molecules in asymmetric unit (asu). The overall structure of CooS2 shows the typical CooS-type CODH architecture of a homodimer with five metal clusters (figure 2A). These clusters show a V-type arrangement with a [4Fe-4S] cluster (the $\mathrm{D}$ cluster) covalently linking the homodimer. All clusters are placed within distances expected to allow fast electron transfer $(\sim 11-12 \AA)$ from the active site (C cluster) at the tip of the $\mathrm{V}$. Each subunit has another [4Fe-4S]-cluster (B cluster) between the $\mathrm{D}$ cluster and the $\mathrm{C}$ cluster. A putative gas channel, formed by a group of conserved hydrophobic residues, leads to the Ni binding site in the $\mathrm{C}$ cluster. The overall structure can be superimposed on that of other CooS-type CODHs, e.g. Desulfovibrio vulgaris $(D v \quad \mathrm{CODH})$, Carboxydothermus hydrogenoformans (Ch CODH II and IV), Rhodospirillum rubrum and Moorella thermoacetica, with rmsd values for $\mathrm{C}_{\alpha}$-atoms of less than $1.4 \AA$ (SI Table S3). SI Figure S1 shows that the gas channels of CooS2 are similar to those observed in other CooS-type CODHs, especially in the vicinity of the $\mathrm{C}$ cluster.

\subsubsection{Active site}

Electron densities of the $\mathrm{C}$ cluster were carefully inspected and the structure of CooS2 refined with a complete $\mathrm{C}$ cluster including $\mathrm{Ni}$, as well as without $\mathrm{Ni}$. The following observations clearly indicate the absence of $\mathrm{Ni}$ in the $\mathrm{C}$ cluster: I) when we initially modelled a complete $\mathrm{C}$ cluster including the $\mathrm{Ni}$ at its binding site with similar occupancy $(\sim 80 \%)$ as the other atoms in the $\mathrm{C}$ cluster, we observed a strong negative $\mathrm{F}_{\mathrm{o}}-\mathrm{F}_{\mathrm{c}}$ difference density on the Ni site (SI Figure S2). II) When scanning the Ni K-edge of the CooS2 crystal, no increase in X-ray fluorescence was observed, indicating that $\mathrm{Ni}$ is absent in the crystal (SI Figure S3). III) Anomalous scattering contributions in difference Fourier maps calculated from Bijvoet pairs of complete datasets collected at $1.732 \AA$ (Fe K-edge) and $1.479 \AA$ ( $\mathrm{Ni} \mathrm{K}$-edge) clearly indicated the presence of $\mathrm{Fe}$ (both wavelengths), but not of $\mathrm{Ni}$ in any of the three copies in the asymmetric unit. In summary, there is either no or only an undetectably small amount of $\mathrm{Ni}$ in the crystal.

We therefore modelled and refined the active site with a Ni-free $\mathrm{C}$ cluster (figure 2B). Anomalous scattering contributions of the four $\mathrm{Fe}$ ions allowed placing of the $\mathrm{C}$ cluster in all chains as a Ni-free [3Fe-3S- $\left.\mu_{3} \mathrm{~S}-\mathrm{Fe}_{1}\right]$-cluster, with the [3Fe-4S]-subcluster having an open site at the Ni-binding site. As in in the Ni-containing $\mathrm{C}$ cluster, $\mathrm{Fe}_{1}$ is in exo position bridged by a $\mu_{3^{-}}$ $\mathrm{S}$ ligand to the [3Fe-3S]-subcluster, but has no water/hydroxo ligand (figure $2 \mathrm{~B}$ and SI Figure S4). The $C$ cluster structures from the three molecules in the asymmetric unit are well superimposable ( $\mathrm{SI}$ Figure S4-C). Cys522, the Ni-coordinating Cys residue, is in the Nicoordinating conformation in chain $\mathrm{B}$, whereas in chains $\mathrm{A}$ and $\mathrm{C}$ it was refined with two conformations (figure 2B and SI Figure S4).

The Ni-free $\mathrm{C}$ cluster of CooS2 is very similar to the $\mathrm{C}$ cluster of $\mathrm{Ch}$ CODH II (PDB ID: 3B53) [14] and $D v$ CODH (PDB ID: 6B6X) [12] with the only apparent difference being the missing $\mathrm{Ni}$ ion, while the remaining parts of the $\mathrm{C}$ cluster are almost unchanged (figure 3 ). The 
Ni-free $\mathrm{C}$ cluster of CooS2 also resembles the [3Fe-4S]-Fe ${ }_{1}$ site of the $\mathrm{C}$ cluster of CODHs produced without CooC $\left(D v \mathrm{CODH}^{-\mathrm{CooC}}\right)$ or devoid of the $\mathrm{D}$ cluster $\left(D v \operatorname{CODH}(\Delta \mathrm{D})^{+\mathrm{CooC}}\right)$, neither of which can be activated by incubation with $\mathrm{Ni}[30]$.

Recently, we suggested that a tight packing of residues at the backside of the [3Fe-4S]subcluster of the $\mathrm{C}$ cluster can contribute to $\mathrm{O}_{2}$-resistance in $\mathrm{Ch} \mathrm{CODH}$ IV, whereas the loose packing is typical of highly $\mathrm{O}_{2}$-sensitive $\mathrm{CODHs}$ [15]. Residues M556, F322, I206, C304, K559 and S557 of CooS2 are in close contact to the backside of the C cluster (figure 3B), resembling more the tightly shielded backside of $\mathrm{Ch}$ CODH IV than the loosely packed Ch CODH II.

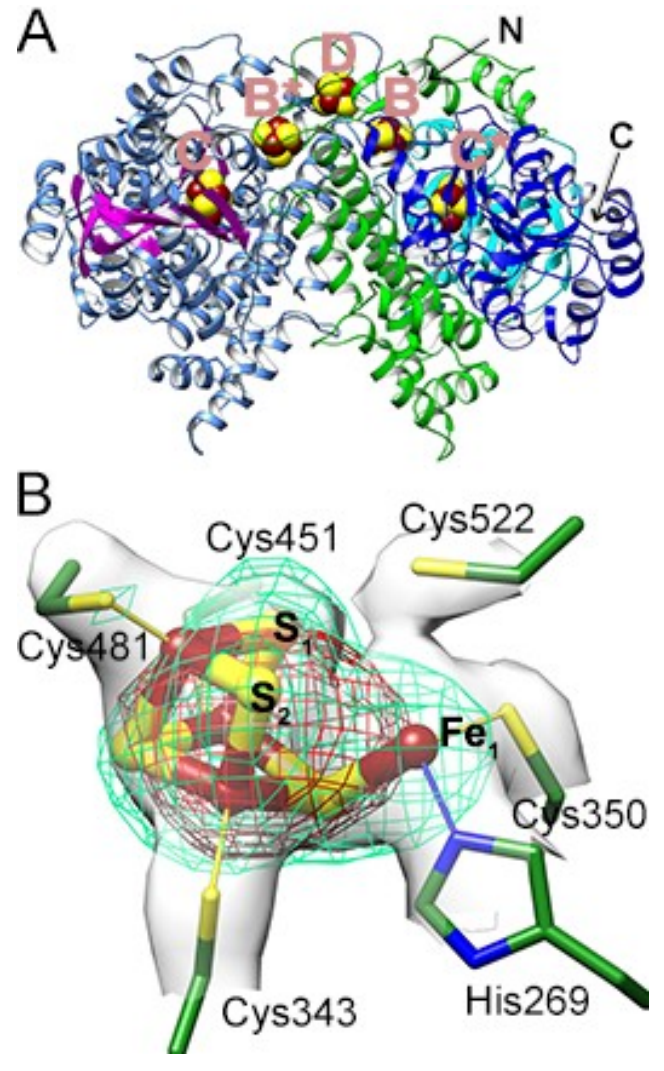

Figure 2: Crystal structure of CooS2. A) Overall dimer structure. One subunit is shown with light-blue helices and pink strands, while the other subunit is colored by domains: $N$ terminal in green, middle in cyan and $C$ terminal in blue. The $\mathrm{B}$ and $\mathrm{C}$ clusters from the same subunits are marked by a star. "N" and " $\mathrm{C}$ " indicate the $\mathrm{N}$ - and $\mathrm{C}$-termini. B) $\mathrm{Ni}$ free $\mathrm{C}$ cluster. Sigma-A weighted electron density maps are shown as: $2 F_{\mathrm{o}}-F_{\mathrm{c}}$ (gray surface at $1.4 \mathrm{rmsd}$ ), $F_{\mathrm{o}}-F_{\mathrm{c}}$ omit (green mesh at $6.0 \mathrm{rmsd}$ ) and Fe-anomalous difference map (red mesh at $4.5 \mathrm{rmsd}$ ). Atoms are colorcoded: $\mathrm{C}$ in dark-green, $\mathrm{N}$ in blue, $\mathrm{S}$ in yellow and $\mathrm{Fe}$ in dark-red. 


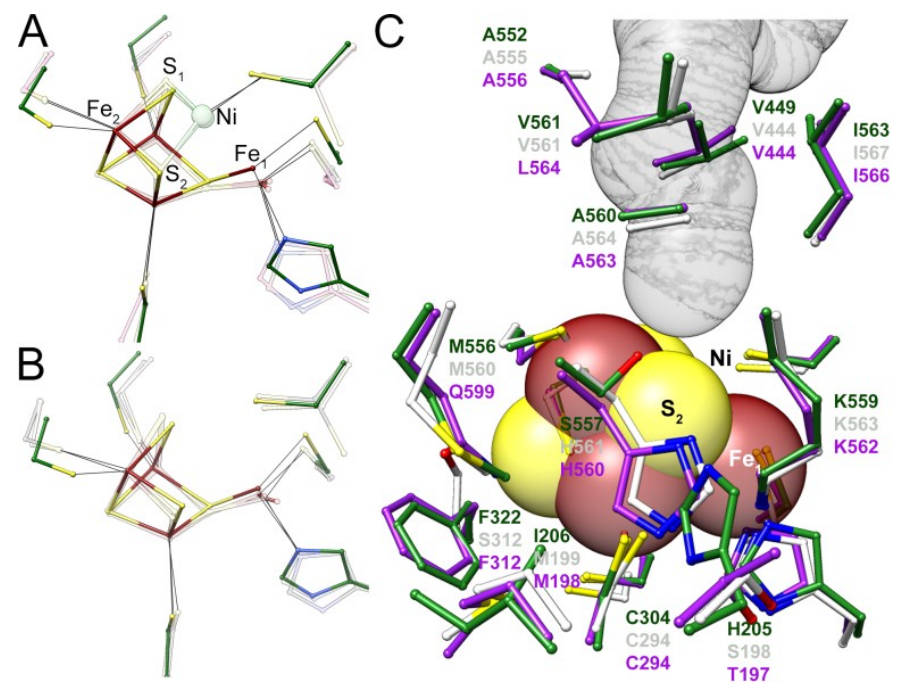

Figure 3: Structure comparison. Superpositions of the active sites of $T C$ CooS2 (green carbon) to: A) Ch CODH II (transparent purple carbon) and $D V$ CODH (transparent white carbon), and B) $D v \operatorname{CODH}(\triangle \mathrm{D})$ (transparent white carbon) and $\mathrm{Dv} \mathrm{CODH}-\mathrm{CooC}$ (transparent gray carbon). An alternative conformation of $\mathrm{Fe}_{1}$ in $\mathrm{DV}$ $\mathrm{CODH}-\mathrm{CoOC}$ is not shown for clarity. Structures in A and B have the same orientation. C) Superposition of $T C$ CooS2 (green carbon), Ch CODH II (gray carbon) and $\mathrm{Ch}$ CODH IV (purple carbon). The hydrophobic gas channel is shown as a gray surface. Van der Waals radii of $\mathrm{Fe}(2.05 \AA$ vdw radius) and $S$ (1.8 $\AA$ vdw radius) in $C$ cluster are shown as spheres. Residues within $4 \AA$ around the $C$ cluster are shown. Residues coordinating $C$ cluster are not indicated.

\subsection{Dependence of activity on potential and catalytic bias}

Electrochemical experiments were performed by adsorbing the enzyme as a film on the surface of a pyrolytic graphite edge electrode (PGE) [31], which ensures electronic connection between the electrode and the electron relay site of the enzyme (most probably the $D$ cluster at the CODH surface). The electrode is rotated to speed up mass-transport of substrates towards the electrode. We used cyclic voltammetry, in which the electrode potential is cycled repeatedly between two values, to study the $\mathrm{CO} / \mathrm{CO}_{2}$ "catalytic bias" [32], that is the relative rate of the reaction when the enzyme is forced to either oxidize $\mathrm{CO}$ or reduce $\mathrm{CO}_{2}$. In the experiments shown here, the current recorded is the "catalytic current", corresponding to electrons produced or consumed in the presence of the substrate $\left(\mathrm{CO}\right.$ or $\left.\mathrm{CO}_{2}\right)$ through the equation:

$$
\mathrm{CO}_{2}+2 \mathrm{H}^{+}+2 \mathrm{e}^{-} \Leftrightarrow \mathrm{CO}+\mathrm{H}_{2} \mathrm{O}
$$

Positive currents correspond to $\mathrm{CO}$ oxidation, whereas negative currents correspond to $\mathrm{CO}_{2}$ reduction. The current is proportional to the enzymatic activity in either direction, according to the equation:

$$
|i|=n F A \Gamma \times k_{c a t}
$$

in which $n=2$ is the number of electrons, $F$ the Faraday constant, $A$ the electrode area, $\Gamma$ the surface concentration of electroactive enzymes and $k_{c a t}$ the turnover frequency.

We systematically used carbonate as the source of $\mathrm{CO}_{2}$ in solution. The concentrations we 
report are the dissolved $\mathrm{CO}_{2}$ concentrations, taking into consideration the equilibrium between dissolved $\mathrm{CO}_{2}$ and carbonate.

Figure 4 shows voltammograms of films of $T c \mathrm{CODH} 1$ or Tc $\mathrm{CODH} 2$ obtained in the presence of either $\mathrm{CO}\left(0.1 \mathrm{mM}\right.$, green curves) or $\mathrm{CO}_{2}(7 \mathrm{mM}$, red curves). Panels $\mathrm{A}$ and $\mathrm{C}$ show the raw data, together with a background signal recorded in the absence of either substrate, and panels $B$ and $D$ show the background-subtracted voltammograms. The current magnitudes are significantly higher for CODH 2 (panels C-D) than for CODH 1 (panels A-B). However, since the quantity of electroactive enzymes on the electrodes is unknown and can possibly greatly vary from one film to another, or from one enzyme to another, it makes no sense to compare the absolute values of the currents. Nevertheless, the voltammetry gives reliable information on the relative rates of catalysis in either direction, as the voltammograms with $\mathrm{CO}$ alone on one hand and $\mathrm{CO}_{2}$ alone on the other hand were recorded with the same film, so that we can compare the reduction and oxidation currents for each $\mathrm{CODH}$. In both cases, the currents for $\mathrm{CO}$ oxidation and for $\mathrm{CO}_{2}$ reduction are of the same magnitude, suggesting that, under these conditions, the reduction and oxidation activities are comparable. We determined the catalytic bias as the ratio of the oxidation current over the reduction current taken either $300 \mathrm{mV}$ above or below the equilibrium potential. We note that, in the case of reversible enzymes, for which a small driving force is enough to generate significant current in either direction [32], comparing the values of the currents too close to the equilibrium potential necessarily yields to a bias close to 1 . In contrast, examining the current values at an overpotential of $\pm 300 \mathrm{mV}$, like we do here, ensures that the ratio represents the intrinsic catalytic bias of the enzyme.

To compare the electrochemical data with the results obtained in solution assays, we determined the activities for $\mathrm{CO}$ oxidation and $\mathrm{CO}_{2}$ reduction at the same $\mathrm{pH}$ as in the electrochemical experiments $(\mathrm{pH} \mathrm{6)}$. All the results are gathered in table 2. Whereas on the electrode the two enzymes seem equally efficient for both the reduction of $\mathrm{CO}_{2}$ and oxidation of $\mathrm{CO}$, the activities measured in solution assays are very strongly biased towards $\mathrm{CO}$ oxidation. 


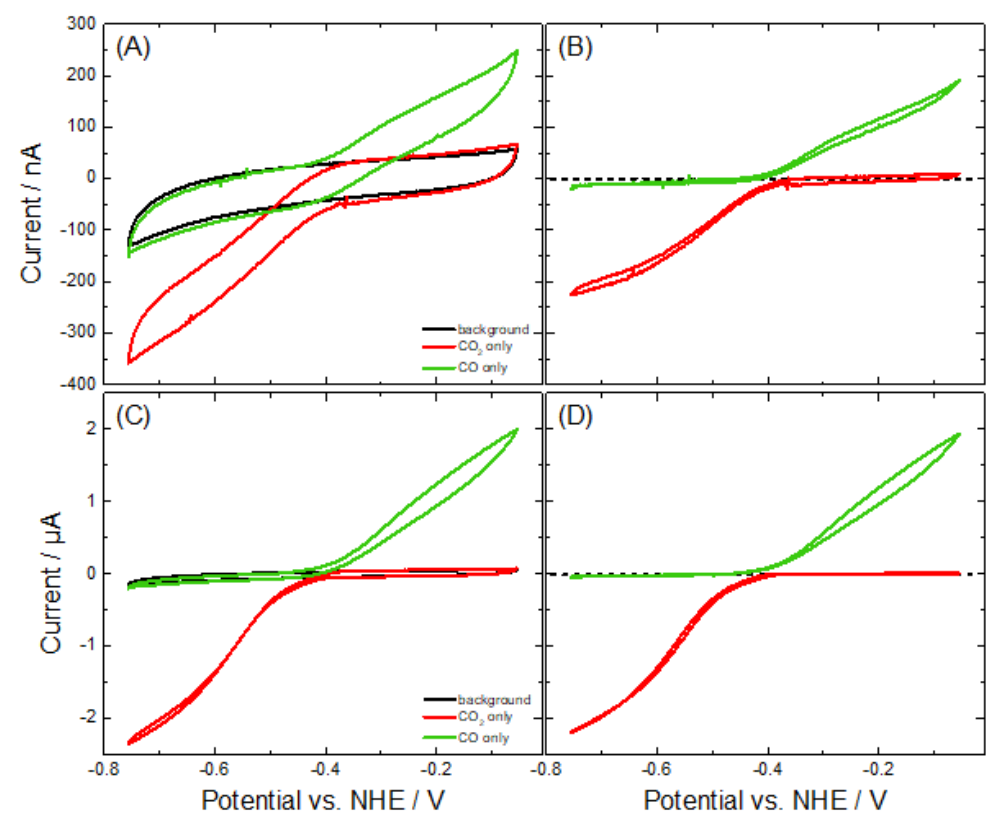

Figure 4: Dependence of $\mathrm{CO}$ oxidation $/ \mathrm{CO}_{2}$ reduction activities as a function of the potential. (AC) Original and (B-D) background subtracted $\mathrm{CVs}$ recorded with films of (A-B) TC $\mathrm{CODH} 1$ and (C-D) TC CODH 2 submitted to injections of $7 \mathrm{mM}$ $\mathrm{CO}_{2}$ (red curves) and $0.1 \mathrm{mM}$ $\mathrm{CO}$ (green curves). Black curves: background $\mathrm{CVs}$ in the absence of substrates. Conditions: $T=25$ ${ }^{\circ} \mathrm{C}, \mathrm{pH} 6$ (200 mM MES), $\omega=$ $5000 \mathrm{rpm}$, scan rate $=20 \mathrm{mV} / \mathrm{s}$.

\begin{tabular}{|l|l|l|l|l|l|l|}
\hline & \multicolumn{3}{|c|}{ Electrochemical experiments } & \multicolumn{3}{c|}{ Solution assays } \\
\hline Enzyme & $\begin{array}{c}\text { CO } \\
\text { oxidation } \\
\text { current } \\
(\mu \mathrm{A})^{\mathrm{a}}\end{array}$ & $\begin{array}{c}\mathrm{CO}_{2} \\
\text { reduction } \\
\text { current } \\
(\mu \mathrm{A})^{\mathrm{a}}\end{array}$ & $\begin{array}{c}\mathrm{Bias} \\
\mathrm{CO} / \mathrm{CO}_{2}\end{array}$ & $\begin{array}{c}\mathrm{CO} \\
\text { oxidation } \\
\text { activity } \\
\left(\mu \mathrm{mol} \mathrm{min}^{-1}\right. \\
\left.\mathrm{mg}^{-1}\right)^{\mathrm{b}}\end{array}$ & $\begin{array}{c}\mathrm{CO}_{2} \\
\text { reduction } \\
\text { activity } \\
\left(\mu \mathrm{mol} \mathrm{min}^{-1}\right. \\
\left.\mathrm{mg}^{-1}\right)^{\mathrm{b}}\end{array}$ & $\begin{array}{c}\text { Bias } \\
\mathrm{CO}^{-1} \mathrm{CO}_{2}\end{array}$ \\
\hline$T c \mathrm{CODH} 1$ & 0.134 & 0.226 & 0.6 & 10 & $0.14 \pm 0.02$ & 71 \\
\hline$T c \mathrm{CODH} 2$ & 1.48 & 2.35 & 0.6 & $70 \pm 10$ & $0.3 \pm 0.05$ & 233 \\
\hline
\end{tabular}

${ }^{a}$ The current was measured at $-0.16 \mathrm{~V}$ for $\mathrm{CO}$ oxidation and $-0.76 \mathrm{~V}$ for $\mathrm{CO}_{2}$ reduction $( \pm 0.3 \mathrm{~V}$ from the equilibrium potential of the couple $\mathrm{CO} / \mathrm{CO}_{2}$ at $\mathrm{pH} 6$, which is $-0.46 \mathrm{~V}$ vs. SHE).

${ }^{\mathrm{b}}$ Activities in solution were measured at $37^{\circ} \mathrm{C}, \mathrm{pH} 6$.

Table 2: Electrochemical currents and solution activities for the oxidation of $\mathrm{CO}$ and reduction of $\mathrm{CO}_{2}$ at $\mathrm{pH}$. The currents are background-subtracted, determined from panels $\mathrm{B}$ and $\mathrm{D}$ in figure 4. 


\subsection{Michaelis constants for $\mathrm{CO}$ and $\mathrm{CO}_{2}$}

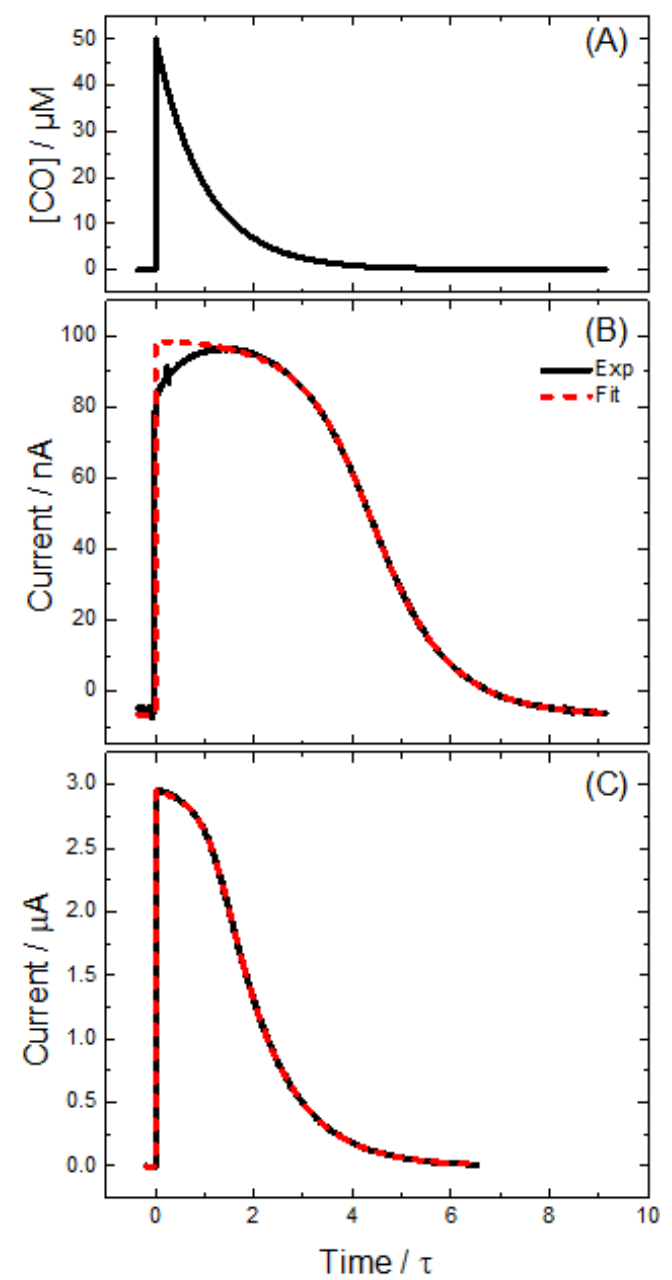

Figure 5: Chronoamperometric measurements of the Michaelis constants relative to $\mathrm{CO}$. The time is normalized by the characteristic time of departure of $\mathrm{CO}$ from solution (determined from the fits of Eq. (2)). A) Concentration of $\mathrm{CO}$ in the cell vs. time. B and $C$ ) Black lines: current observed with a film of (B) $T c \mathrm{CODH} 1$ and (C) Tc $\mathrm{CODH} 2$ submitted to a single injection of $50 \mu \mathrm{M} \mathrm{CO}$ at $t=0$ (the $\mathrm{CO}$ departure time constants are $\tau=54 \mathrm{~s}$ and $35 \mathrm{~s}$ for $B$ and $C$, respectively). Experimental conditions: $T$ $=25^{\circ} \mathrm{C}, \mathrm{pH} 7$, electrode rotation rate $\omega=5000$ rpm, $E=-0.31 \mathrm{~V}$ vs. SHE. Red dashed lines: fit of the chronoamperograms using equation (9) (model (c)) in [23]. Parameters of the fits: B) $K_{m}=0.3 \mu \mathrm{M}$, $\mathrm{nFA} \mu=0.35 \mu \mathrm{A} / \mu \mathrm{M}, \mathrm{nFAm}=0.18 \mu \mathrm{A} / \mu \mathrm{M}, i_{0}=-6.7$ $\mathrm{nA},[\mathrm{CO}]_{0}=50 \mu \mathrm{M}, \tau=54 \mathrm{~s}$, and C) $K_{m}=0.9 \mu \mathrm{M}$, $\mathrm{nFA} \mu=3.37 \mu \mathrm{A} / \mu \mathrm{M}, \mathrm{nFAm}=0.21 \mu \mathrm{A} / \mu \mathrm{M}, i_{0}=-1.2$ $\mathrm{nA},[\mathrm{CO}]_{0}=50 \mu \mathrm{M}, \tau=35 \mathrm{~s}$.

For the determination of the Michaelis constants relative to $\mathrm{CO}$ and $\mathrm{CO}_{2}, K_{m}$, we used chronoamperometry, in which a constant potential is applied to the electrode and the current is measured as a function of the time. In this way, we can study time-dependent processes, such as the response in current of the $\mathrm{CODH}$ film to a transient exposure to $\mathrm{CO}$ or $\mathrm{CO}_{2}$. We have previously shown that the injection of a dissolved gas into an open electrochemical cell results in a near-instant increase in concentration followed by a perfectly mono-exponential decrease over time [21,33] (panel $A$ in figure 5). This makes it possible to probe the response to a large range of substrate concentration in a single experiment, allowing the determination of even very small values of $K_{m}$ [15]. Figure 5 shows the response in current over time of films of CODH 1 and 2 poised at a constant potential after the injection of an aliquot of CO-saturated buffer. In both cases, the film responds by the instant appearance of a $\mathrm{CO}$ oxidation current, followed by a short-lived plateau, in which the current varies little in spite of the decrease in the concentration of $\mathrm{CO}$, indicating that the enzymes are saturated with $\mathrm{CO}$. In the case of CODH 1 , the current even slowly increases further during the minute that follows the injection, reflecting 
an increase in activity, probably an activation by CO. After the plateau, the current decreases in a sigmoidal fashion, ending in a perfect mono-exponential decay. This is exactly as observed in the case of other CODHs [15,23]. CODHs are in general so active for CO oxidation that the electrode rotation cannot prevent depletion of $\mathrm{CO}$ in the vicinity of the electrode: therefore, mass-transport limitations have to be taken into account. We did so by fitting the model described in ref. [23] to the chronoamperometric traces to determine the values of $K_{m}$ for CO oxidation: $0.26 \pm 0.03 \mu \mathrm{M}$ for TC CODH $1(n=14)$, and $0.9 \pm 0.3 \mu \mathrm{M}$ for Tc CODH $2(n=30)$ at $\mathrm{T}=25^{\circ} \mathrm{C}, \mathrm{pH}=7, \mathrm{E}=-0.31 \mathrm{~V}$ vs. SHE. The experiments were performed with films of variable coverage, and hence under varying conditions of mass-transport limitation, which decreases the influence of possible artifacts of mass-transport limitation. The other parameters of the model are $i_{0}$ : an offset current when no substrate is present, $m$ : the mass-transport coefficient, here determined as the product $n F A m$ (where $n$ is the number of electrons, $F$ the Faraday constant and $A$ the electrode area), $\mu=\Gamma \times \mathrm{k}_{\text {eff }}$ : the product of the enzymatic surface concentration by the catalytic efficiency (as in the case of $m$, determined as the product $n F A \mu$ ), $\tau$ : the time constant of $\mathrm{CO}$ departure from the solution.

We used a similar strategy for determining the Michaelis constants for $\mathrm{CO}_{2}$ reduction. We submitted films of the enzyme to injections of $\mathrm{CO}_{2}$ (under the form of carbonate solutions, see the methods section) and monitored the resulting $\mathrm{CO}_{2}$ reduction (negative) currents over time. The results are shown in figure 6. The observed behaviour depends on the enzyme. In the case of $\mathrm{CODH} 1$ (figure $6 \mathrm{~B}$ ), after injection of $\mathrm{CO}_{2}$ a slowly decreasing plateau is first observed, followed by a faster decrease, suggesting that the initial concentration is above the $K_{m}$ value. On the contrary, in the case of $\mathrm{CODH} 2$, we always observed a pure mono-exponential decay of the current after injection of $\mathrm{CO}_{2}$ : in that case, the $K_{m}$ value is significantly larger than initial $\mathrm{CO}_{2}$ concentration. The catalytic efficiency of the $\mathrm{CODHs}$ for $\mathrm{CO}_{2}$ is much smaller than for $\mathrm{CO}$, so it was not necessary to take into account mass-transport limitation when fitting the data [23]. For both enzymes, we have therefore fitted the Michaelis-Menten equation to the data:

$$
i(t)=\frac{i_{m}}{1+\frac{K_{m}}{\left[\mathrm{CO}_{2}\right](t)}}+i_{0}
$$

in which $i(t)$ is the current, $i_{m}$ the maximum current (at saturation), $K_{m}$ the Michaelis constant, $i_{0}$ an offset current, and $\left[\mathrm{CO}_{2}\right](t)$ the concentration of $\mathrm{CO}_{2}$ (which decreases exponentially). In the case of CODH 1, we could determine a value of $K_{m}=0.3 \pm 0.1 \mathrm{mM}$. In the case of CODH 2, the value of $K_{m}$ could not be determined because we could not approach saturation even at $\left[\mathrm{CO}_{2}\right]=7 \mathrm{mM}$. Indeed, we show in SI Figure S5 and Table S4 that the fits are equally good with any value of $K_{m}>7 \mathrm{mM}$. 


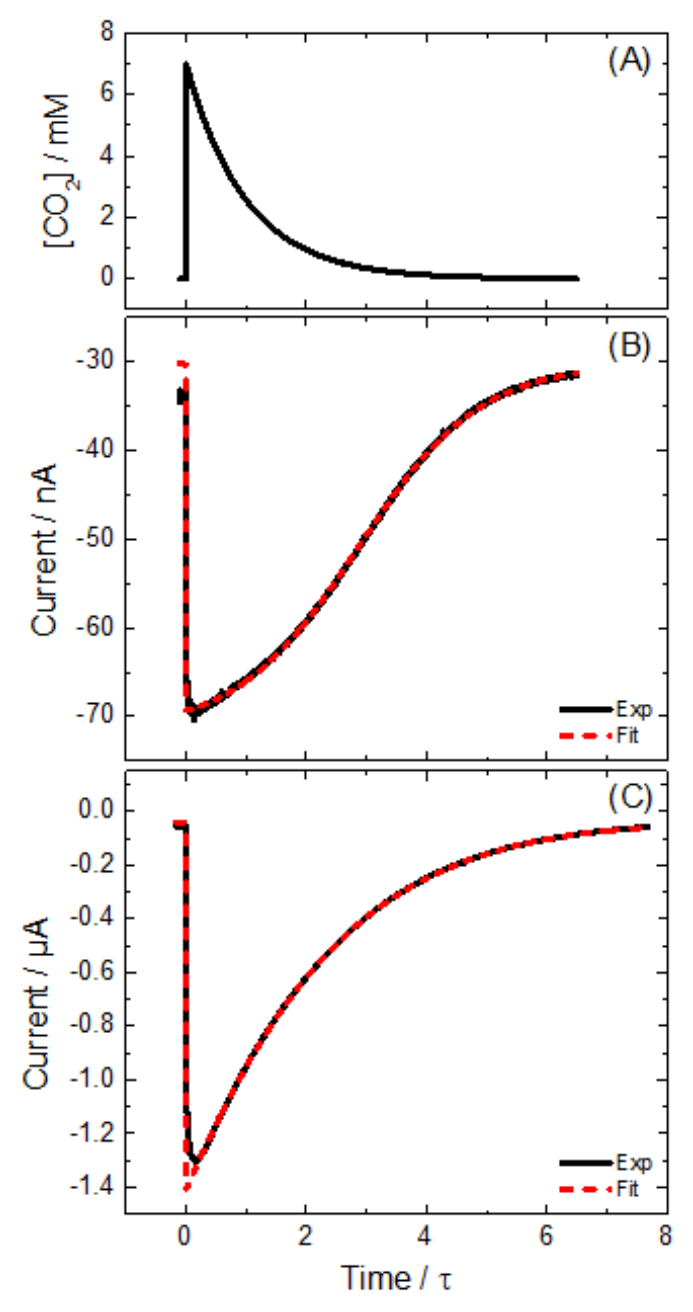

Figure 6: Chronoamperometric measurements of the Michaelis constants relative to $\mathrm{CO}_{2}$. The time is normalized by the characteristic time of departure of $\mathrm{CO}_{2}$ (determined from the fits of Eq. (2)). A) Concentration of $\mathrm{CO}_{2}$ in the cell vs. time. $\mathrm{B}$ and $\mathrm{C}$ ) Black lines: current generated by a film of (B) TC CODH 1 and (C) TC CODH 2 submitted to a single injection of $10 \mathrm{mM}$ carbonate at $\mathrm{t}=0$ (the $\mathrm{CO}_{2}$ departure time constant are $\tau=139$ and $199 \mathrm{~s}$ for $\mathrm{B}$ and $C$, respectively). Experimental conditions: $T=$ $25^{\circ} \mathrm{C}, \mathrm{pH} 6$ (200 mM MES), $\omega=5000 \mathrm{rpm}, \mathrm{E}=-$ $0.66 \mathrm{~V}$ vs. SHE. Red dashed lines: fit of the chronoamperograms using Eq. (2). Parameters of the fits: B) $K_{m}=0.42 \mathrm{mM}, i_{\mathrm{m}}=-42 \mathrm{nA}, i_{0}=-30 \mathrm{nA}$, $\left[\mathrm{CO}_{2}\right]_{0}=7 \mathrm{mM}, \tau=139 \mathrm{~s}$, and C) $K_{m}=17.1 \mathrm{mM}, i_{\mathrm{m}}$ $=-4.8 \mu \mathrm{A}, i_{0}=-24 \mathrm{nA},\left[\mathrm{CO}_{2}\right]_{0}=7 \mathrm{mM}, \tau=199 \mathrm{~s}$.

\subsection{Product inhibition}

We also used chronoamperometric experiments to search for any evidence of product inhibition, that is the inhibition of $\mathrm{CO}$ oxidation by $\mathrm{CO}_{2}$ and the inhibition of $\mathrm{CO}_{2}$ reduction by $\mathrm{CO}$. Regarding the former, we used two-injection experiments such as those in SI Figure S6, in which one first injects a solution of $\mathrm{CO}$, like in the experiments shown in figure 5 , followed by a solution of carbonate. SI Figure S6 shows that, even at the highest concentrations of carbonate used $(5 \mathrm{mM})$, its presence has no effect on the $\mathrm{CO}$ oxidation activity of either CODH 1 or $\mathrm{CODH} 2$. We used the same strategy to study the impact of $\mathrm{CO}$ on $\mathrm{CO}_{2}$ reduction by injecting $\mathrm{CO}_{2}$ and, then, $\mathrm{CO}$. Figure 7 shows the resulting chronoamperometric traces. For both $\mathrm{CODH} 1$ and 2, the injection of $\mathrm{CO}$ results in an instant decrease in the $\mathrm{CO}_{2}$ reduction current (the current becomes less negative), showing that $\mathrm{CO}$ is a strong inhibitor of $\mathrm{CO}_{2}$ reduction. Depending on the enzyme (and thus on the magnitude of the inhibition), the activity can either keep on decreasing due to the overall decrease in $\mathrm{CO}_{2}$ concentration (figure $7 \mathrm{C}$ ), or transiently increase as $\mathrm{CO}$ is removed from the electrochemical buffer before decreasing again as $\mathrm{CO}_{2}$ is removed too (figure $7 \mathrm{~B}$ ). In both cases, we could fit the following equation, corresponding to 
competitive inhibition of $\mathrm{CO}_{2}$ reduction by $\mathrm{CO}$, to the experimental traces:

$$
i(t)=\frac{i_{m}}{1+\frac{K_{m}}{\left[\mathrm{CO}_{2}\right](t)} \times\left(1+\frac{[C O](t)}{K_{i}}\right)}+i_{0}
$$

in which $i_{m}$ is the maximum current (at saturation without inhibition), $K_{m}$ the Michaelis constant relative to $\mathrm{CO}_{2}$ reduction, $K_{i}$ the inhibition constant, and $i_{0}$ an offset current. The concentrations of $\mathrm{CO}$ and $\mathrm{CO}_{2}$ are given by the following equations:

$$
\begin{gathered}
{\left[\mathrm{CO}_{2}\right](t)=\left[\mathrm{CO}_{2}\right]_{0} \exp \left(-\frac{t-t_{0}}{\tau_{\mathrm{CO}_{2}}}\right)} \\
{[\mathrm{CO}](t)=[\mathrm{CO}]_{0} \exp \left(-\frac{t-t_{1}}{\tau_{\mathrm{CO}}}\right)}
\end{gathered}
$$

in which $\left[\mathrm{CO}_{2}\right]_{0}$ and $[\mathrm{CO}]_{0}$ are the injected concentrations, $t_{0}$ and $t_{1}$ the injection times, and $\tau_{\mathrm{CO}_{2}}$ and $\tau_{\mathrm{CO}}$ the departure time constants of $\mathrm{CO}_{2}$ and $\mathrm{CO}$, respectively. This equation proved valid for $\mathrm{CO}$ inhibition of $\mathrm{H}_{2}$ oxidation by hydrogenase, see Fig. 54 and Eq. 58 in ref. [34]. The fits are shown as dashed lines in figure 7, and they convincingly reproduce the data. Analyzing several experiments with this model yielded the following values of the inhibition constant $K_{i}=0.39 \pm$ $0.07 \mu \mathrm{M}$ for $\mathrm{CODH} 1$, and $14 \pm 5 \mu \mathrm{M}$ for $\mathrm{CODH} 2$, at $\mathrm{T}=25^{\circ} \mathrm{C}, \mathrm{pH}=6, \mathrm{E}=-0.66 \mathrm{~V}$ vs. SHE. To avoid parameter underdetermination, we imposed the values of $K_{m}$ based on the experiments of figure 6 for fitting the data. We found that the value of $K_{i}$ determined from the fits depended on the experiment and on the actual value of $K_{m}$ used for the determination; the uncertainty reflects both variations. It is interesting to note that the departure times determined from the fits are systematically larger for $\mathrm{CO}_{2}$ than for $\mathrm{CO}$ (about two to three fold). This is expected for two reasons: first, because of the equilibrium between $\mathrm{CO}_{2}$ and $\mathrm{HCO}_{3}{ }^{-}$, only a fraction of the "total $\mathrm{CO}_{2}$ " species is available under the form of a dissolved gas, which slows down the exchange. Second, given that $\mathrm{CO}_{2}$ is significantly more hydrophilic than $\mathrm{CO}$, it is not surprising that the rate of departure of $\mathrm{CO}_{2}$ itself from water is slower than that of $\mathrm{CO}$. 


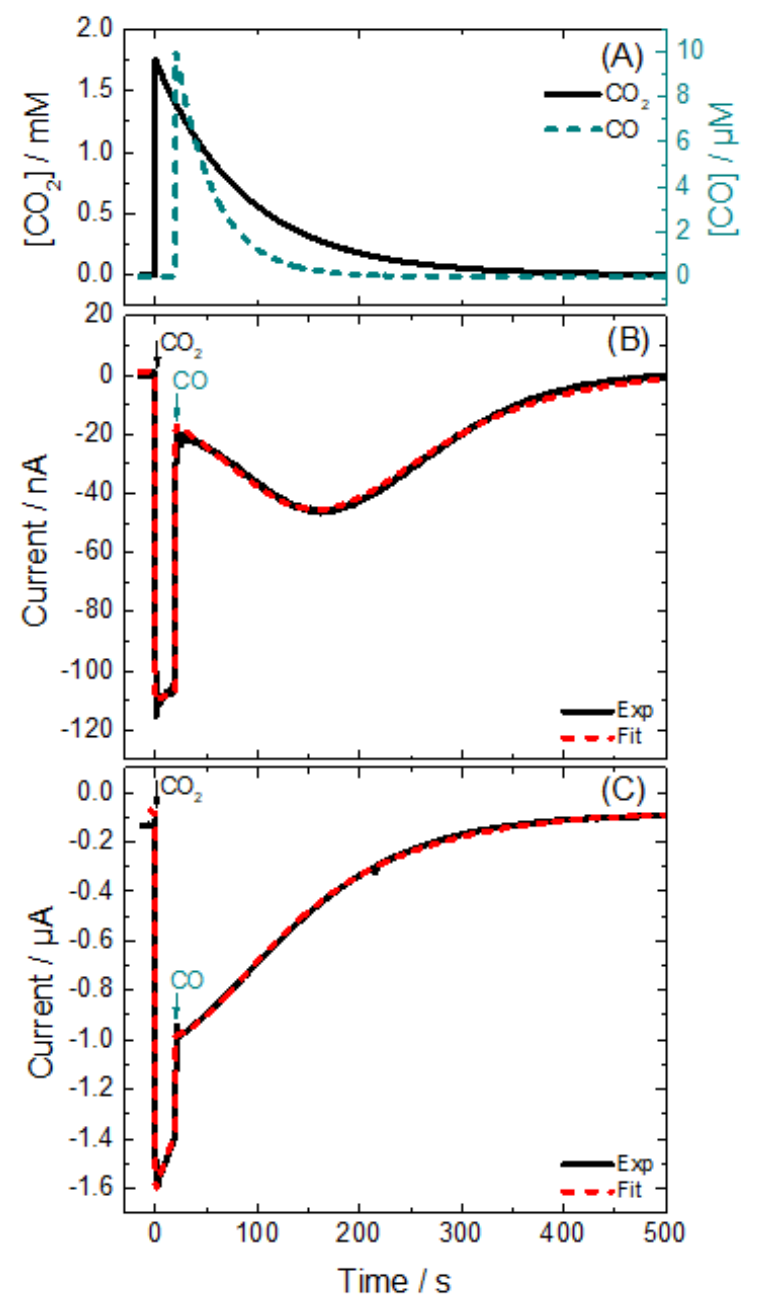

Figure 7: Inhibition of $\mathrm{CO}_{2}$ reduction by $\mathrm{CO}$. A) Concentration of $\mathrm{CO}_{2}$ (solid line) and $\mathrm{CO}$ (dotted line) vs. time, deduced from the amount injected (2.5 mM carbonate and 10 $\mu \mathrm{M} \mathrm{CO}$ ) and the time constant of the final exponential decrease of the current (note that the two concentrations are in different scales). B and $\mathrm{C}$ ) Current generated by a film of (B) Tc CODH 1 and (C) Tc CODH 2 submitted to an injection of $2.5 \mathrm{mM}$ carbonate at $\mathrm{t}=0$ and an injection of $10 \mu \mathrm{M} \mathrm{CO}$ at $\mathrm{t}=20$ s. Experimental conditions: $\mathrm{T}=25^{\circ} \mathrm{C}, \mathrm{pH} 6$ (200 mM MES), $\omega=5000 \mathrm{rpm}, \mathrm{E}=-0.66 \mathrm{~V}$ vs. SHE. Red dashed lines: fit of the chronoamperograms using Eq. (3). Parameters of the fits: $\mathrm{B})\left[\mathrm{CO}_{2}\right]_{0}=1.75 \mathrm{mM}$, $[\mathrm{CO}]_{0}=10 \mu \mathrm{M}, i_{\mathrm{m}}=-0.13 \mu \mathrm{A}, i_{0}=1.14 \mathrm{nA}$, $\tau_{\mathrm{CO} 2}=88 \mathrm{~s}, \tau_{\mathrm{CO}}=38 \mathrm{~s}, K_{m}$ (imposed) $=0.3$ $\mathrm{mM}, K_{i}=0.36 \mu \mathrm{M}$; C) $\left[\mathrm{CO}_{2}\right]_{0}=1.75 \mathrm{mM}$, $[\mathrm{CO}]_{0}=10 \mu \mathrm{M}, i_{\mathrm{m}}=-16.4 \mu \mathrm{A}, i_{0}=-74 \mathrm{nA}, \tau_{\mathrm{CO} 2}$ $=108 \mathrm{~s}, \tau_{\mathrm{CO}}=40 \mathrm{~s}, K_{m}($ imposed $)=17 \mathrm{mM}, K_{i}$ $=21.5 \mu \mathrm{M}$.

\subsection{Inhibition by $\mathrm{O}_{2}$}

We used the 6-injection procedure described in ref. [20] to characterize the inhibition of both enzymes by $\mathrm{O}_{2}$. Briefly, the approach consists in subjecting a film of $\mathrm{CODH}$ to an injection of a CO-saturated solution, followed by an injection of $\mathrm{O}_{2}$ to inhibit the enzyme. The activity is followed immediately after $\mathrm{O}_{2}$ injection, and then probed again by a second injection of $\mathrm{CO}$ after all the $\mathrm{O}_{2}$ has escaped from the solution. Finally, a third $\mathrm{CO}$ injection following a poise at low potential is used to assess the extent of reductive reactivations (the other three CO injections serve as controls, see SI Figure S7 and ref. [20] for more details). Figure 8 shows the resulting values for both $\mathrm{CODH} 1$ and $\mathrm{CODH} 2$. The red points are the residual activities just after $\mathrm{O}_{2}$ exposure, the blue ones after $\mathrm{O}_{2}$ departure, and the green ones after the reductive poise. Both CODHs reactivate significantly once $\mathrm{O}_{2}$ has been removed from the solution. However, whereas a reductive poise reactivates $\mathrm{CODH} 1$ (the green curve in panel $\mathrm{A}$ is offset with respect to the blue one), it has no effect on CODH 2 (compare the green and blue curves in panel B). For both 
CODHs, longer and lower potential poises (up to $180 \mathrm{~s}$ and down to $-0.76 \mathrm{~V}$ vs. SHE) make no difference (data not shown). We also determined the second-order rate constant of reaction between $\mathrm{CODH}$ and $\mathrm{O}_{2}$ by fitting a mono-exponential decay to the fast decrease in activity following the injection of $\mathrm{O}_{2}$, as described in [20]. The resulting apparent first-order rates as a function of the injected $\mathrm{O}_{2}$ concentration are shown in figure 9 , and the deduced second-order rates are shown in table 3.

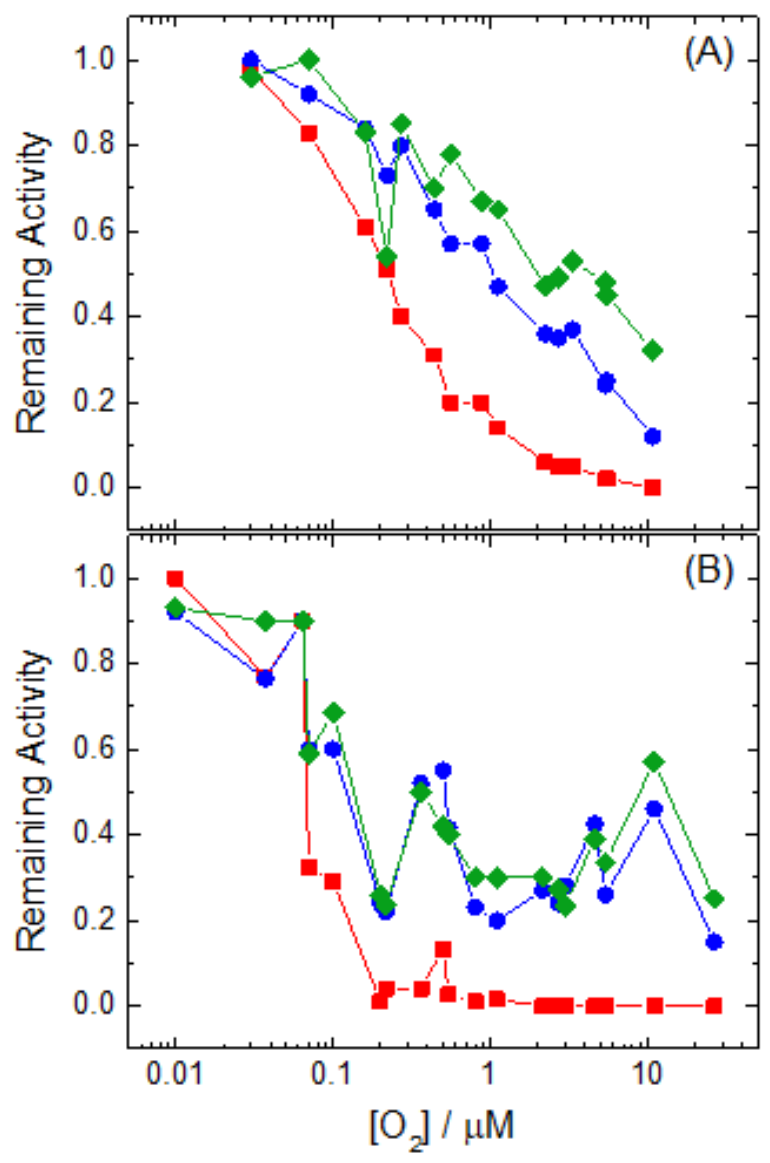

Figure 8: Effect of different $\mathrm{O}_{2}$ concentrations on (A) Tc CODH 1 and (B) Tc CODH 2 studied by PFV. Red squares: activity remaining just after $\mathrm{O}_{2}$ injection; blue circles: activity recovered after removal of $\mathrm{O}_{2}$; green diamond: activity recovered after a poise at low potential. Conditions: $\mathrm{T}=25^{\circ} \mathrm{C}, \mathrm{pH} 7, \omega$ $=5000 \mathrm{rpm}, \mathrm{E}=-0.31 \mathrm{~V}$ vs. SHE. 


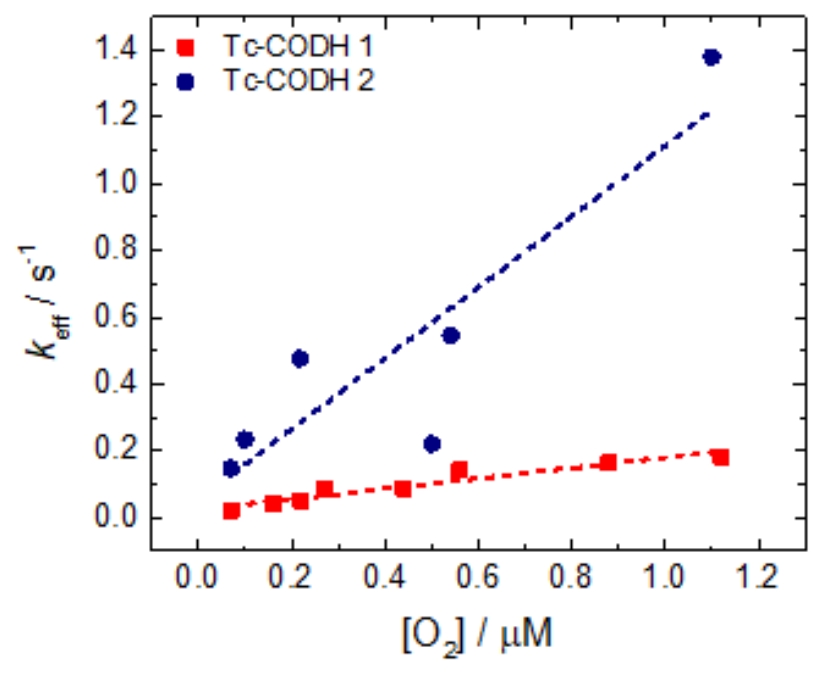

Figure 9: Pseudo-first-order rate constants of inhibition of TC CODH 1 (red squares) and $T c \mathrm{CODH} 2$ (blue circles) as a function of the injected $\mathrm{O}_{2}$ concentration. The dashed lines are the linear fits to find the second-order rate constants (the results are shown in table 3). Conditions: $\mathrm{T}=25^{\circ} \mathrm{C}$, $\mathrm{pH} 7, \omega=5000 \mathrm{rpm}, \mathrm{E}=-0.31 \mathrm{~V}$ vs. SHE.

Table 3 summarizes all the results obtained with the different CODHs that we have characterized in this work and previously. For the sake of comparing the properties of the different CODHs, we introduce the following new measures of the oxygen sensitivity. For each of the conditions of the curves in figure 8 (e.g. just after exposure to $\mathrm{O}_{2}$, after $\mathrm{O}_{2}$ departure, and after reductive poise), we have determined the value of the injected concentration for which $50 \%$ of the initial activity is left. We call these quantities $K_{i}^{i m m}$ (just after injection) $K_{i}^{o x}$ (after $\mathrm{O}_{2}$ departure) and $K_{i}^{\text {red }}$ (after reductive poise). Their values are shown in table 3, along with the values of the second-order rate constant of reaction with $\mathrm{O}_{2}$. The errors are estimated from the "width" of the crossing of the $50 \%$ activity line.

\begin{tabular}{|l|l|l|l|l|l|}
\hline & $\begin{array}{l}K_{i}^{\text {imm }}(\mu \mathrm{M} \\
\left.\mathrm{O}_{2}\right)\end{array}$ & $K_{i}^{\text {ox }}\left(\mu \mathrm{M} \mathrm{O}_{2}\right)$ & $K_{i}^{\text {red }}\left(\mu \mathrm{M} \mathrm{O}_{2}\right)$ & $\begin{array}{l}\text { Bimolecular } \\
\text { rate constant } \\
\left(\mathrm{s}^{-1} \mu \mathrm{M}^{-1}\right)\end{array}$ & Reference \\
\hline$T c$ CODH 1 & $0.2 \pm 0.1$ & $1.1 \pm 0.4$ & $3 \pm 2$ & $0.15 \pm 0.02$ & (this work) \\
\hline$T c$ CODH 2 & $0.06 \pm 0.03$ & $0.8 \pm 0.4$ & $0.8 \pm 0.4$ & $1.1 \pm 0.3$ & (this work) \\
\hline$D v$ CODH & $0.06 \pm 0.03$ & $3 \pm 2$ & $>20$ & $5.3 \pm 0.4$ & {$[20]$} \\
\hline Ch CODH II & $0.2 \pm 0.1$ & $0.8 \pm 0.2$ & $1.2 \pm 0.4$ & $12 \pm 2$ & {$[20]$} \\
\hline Ch CODH IV & $(\mathrm{ND})$ & $10 \pm 5$ & $10 \pm 5$ & $(\mathrm{ND})$ & {$[15]$} \\
\hline
\end{tabular}

Table 3: Summary of the inhibition of different CODHs by $\mathrm{O}_{2}$. The first three columns represent the quantity of $\mathrm{O}_{2}$ necessary to lose over $50 \%$ of the activity just after the injection (first column), after $\mathrm{O}_{2}$ departure (second column) or after a reductive poise (third column), called respectively $K_{i}^{i m m}, K_{i}^{o x}$ and $K_{i}^{r e d}$. The fourth column lists the bimolecular rate constant of reaction with $\mathrm{O}_{2}$. Conditions: $\mathrm{T}=25^{\circ} \mathrm{C}, \mathrm{pH} 7, \omega=5000 \mathrm{rpm}, \mathrm{E}=-0.31 \mathrm{~V}$ vs. SHE. 


\section{Discussion}

Using $D$. fuctosovorans as a host for production, we have purified and characterized for the first time the two CODHs from the archaeon Thermococcus sp. AM4, which are the first isolated CooS-type archaeal CODHs characterized so far. Our initial attempts to produce the two enzymes in Escherichia coli failed [35], but we succeeded in using $D$. fuctosovorans as a host and the same expression and purification strategies as previous described for the production of $D$. vulgaris CODH. This shows that $D$. fructosovorans is a good system for the expression of recombinant $\mathrm{CODHs}$, and it also raises the question of why only Ch CODHs could be successfully overexpressed in E. coli so far.

As previously shown for $D v \mathrm{CODH}$, the $\mathrm{Ni}$ content of $T c \mathrm{CODH} 1$ and 2 preparations dramatically depends on the presence of the corresponding CooC protein. This definitely settles $\mathrm{CooC}$ as an accessory protein essential for $\mathrm{Ni}$ insertion into the $\mathrm{CODH}$ active site. CooC is a dimer which is believed to coordinate $\mathrm{Ni}$ at the interface of the two monomers. Two conserved cysteines from each monomer are involved in Ni coordination [36]. That the CODH produced in the absence of CooC cannot be activated by exogenous Ni shows that CooC is not just involved in the delivery of the metal, but also in the preparation of the active site for receiving the nickel [37] This is consistent with our previous investigation of $D v \operatorname{CODH}[18,30]$. Our data show that the CODHs matured in the presence of either CooC1 or CooC2, which share 40\% identity (SI Figure S9), have similar values of activity and nickel content. This demonstrates for the first time that two distinct $\mathrm{CooC}$ from a single organism are functionally exchangeable.

However, co-expressing either CooS1 or CooS2 with CooC3 did not yield any significant increase in the nickel loading nor in the activity of the enzymes with respect to the expression in the absence of $\mathrm{CooC}$. This could be the result of a lack of expression of $\mathrm{CooC} 3$ with the constructions we have used, but it might also mean that CooC3 is in fact not a CODH maturation factor. It may be rather involved in the maturation of a yet unknown nickel protein, or even in divalent cations trafficking.

We have used a number of electrochemical methods previously developed in our lab to compare the catalytic properties of $T C \mathrm{CODH} 1$ and 2. Based on the values of the Michaelis constants for their substrates, the physiological direction of the reaction seems to be the oxidation of $\mathrm{CO}$, since the Michaelis constants are in the (sub)micromolar range for $\mathrm{CO}$, but in the millimolar range (or more) for $\mathrm{CO}_{2}$. However, it should be emphasized that at high $\mathrm{CO}_{2}$ concentrations ( $7 \mathrm{mM}$, Figure 4$)$ the currents for the reduction of $\mathrm{CO}_{2}$ are comparable to those for the oxidation of $\mathrm{CO}$. This suggests that the limiting currents under saturating conditions are at least as high for $\mathrm{CO}_{2}$ (for which the enzymes are not fully saturated in figure 4) as for $\mathrm{CO}$ (for which the enzymes are saturated in the voltammograms of figure 4). This raises the question of the origin of the large difference in $K_{m}$ between the two substrates: if they can be eventually processed at comparable rates, does the difference lie in the access channel or in the ultimate binding step?

As observed in the literature with other CODHs [38,39], solution assays of Tc CODH 1 and 2 show much slower $\mathrm{CO}_{2}$ reduction than $\mathrm{CO}$ oxidation. We argue here, however, that these numbers are misleading since the voltammograms of figure 4 show that, when immobilized on electrodes, the two CODHs are equally fast at reducing $\mathrm{CO}_{2}$ as at oxidizing $\mathrm{CO}$. This is not a property of TC CODHs, since it has also been observed for the CODHs of Ch [40,41] and Dv [42]. We think that the electrochemical data reflect the intrinsic properties of the CODHs, since it 
would be unlikely that the interaction of the CODHs with the electrode either selectively speed up the $\mathrm{CO}_{2}$ reduction or selectively slow down the $\mathrm{CO}$ oxidation. For the sake of the comparison with literature data, we have used the commonly used method for measuring the $\mathrm{CO}_{2}$ reduction activity of CODHs. However, from our data, we propose that the "traditional" solution assays for the reduction of $\mathrm{CO}_{2}$ are not optimal. This may be due to a number of factors: the solution assays use methyl viologen as electron donor, whose reduction potential is higher than that of the $\mathrm{CO}_{2} / \mathrm{CO}$ couple and provides low driving force for $\mathrm{CO}_{2}$ reduction. Moreover, it is possible that the concentration of reduced methyl viologen used is lower than the corresponding $K_{m}$. Finally, the assays rely on myoglobin for the detection of the produced $\mathrm{CO}$, which might not trap all the produced $\mathrm{CO}$ molecules, resulting in the activity being underestimated. It may be possible to improve the $\mathrm{CO}_{2}$ reduction assay by using other reductants such as titanium citrate and using gas chromatography for the detection of the product.

As was observed before for $\mathrm{Ch} \mathrm{CODHs}$ [43], $\mathrm{CO}_{2}$ does not inhibit the oxidation of $\mathrm{CO}$, while $\mathrm{CO}$ acts as a strong inhibitor of $\mathrm{CO}_{2}$ reduction. This mirrors the relative affinities of the CODHs for their substrates: very high affinities $\left(K_{m}\right.$ in the micromolar range or below) for CO oxidation, and very low affinities $\left(K_{m}\right.$ in the millimolar range or above) for $\mathrm{CO}_{2}$ reduction. In the case of a simple one substrate/one product model of bidirectional catalysis, one expects the $K_{m}$ value in one direction of the reaction to be the $K_{i}$, value for the inhibition of the other direction, which is qualitatively compatible with the conclusions from our data. However, the agreement is not quantitative: deviations could be explained by the fact that, in addition to the changes in concentrations of substrate/product (accounted for by the simple model), the CO oxidation and $\mathrm{CO}_{2}$ reduction experiments differ by the electrode potential. Further work is required to better understand the transport and the binding of the substrates.

Both $T c \mathrm{CODH}$ are rather sensitive to $\mathrm{O}_{2}(\mathrm{CODH} 1$ slightly less than $\mathrm{CODH} 2)$ and, in terms of residual activity after exposure, behave like the previously characterized $\mathrm{Ch} \mathrm{CODH}$ II (table 3) [20]. However, their bimolecular rate constants of reaction with $\mathrm{O}_{2}$ are markedly lower, especially for $\mathrm{CODH} 1$ which reacts with $\mathrm{O}_{2}$ one hundred times more slowly than $\mathrm{Ch} \mathrm{CODH}$ II. The lower bimolecular rate constant of $\mathrm{CODH} 1$ is consistent with the fact that this enzyme keeps a larger amount of activity just after the injection of $\mathrm{O}_{2}$. However, the activity kept just after injection of $\mathrm{O}_{2}$ by $\mathrm{CODH} 1$ is comparable to that of $\mathrm{Dv} \mathrm{CODH}$, in spite of a 40 -fold increase in the bimolecular rate constant, showing that the latter is not the single determinant of the oxygen sensitivity, even when only considering the immediate response. It is remarkable that the amino acids that line at the back of the $\mathrm{C}$ cluster in the structure of TC CODH 2 are closely packed, as was observed for $\mathrm{Ch} \mathrm{CODH}$ IV, and in contrast with $\mathrm{Ch} \mathrm{CODH}$ II. The second-order rate constant for the reaction of $\mathrm{Ch} \mathrm{CODH}$ IV with $\mathrm{O}_{2}$ could not be determined, but this enzyme is very resistant to $\mathrm{O}_{2}$. We speculate here that the resistance of $\mathrm{Ch}$ CODH IV and the low bimolecular rate constants for the reaction between $\mathrm{O}_{2}$ and both $T c \mathrm{CODHs}$ may originate from the close packing of the residues that surround the $\mathrm{C}$ cluster (these residues are conserved in TC CODH 1 and 2, see SI Figure S8). Nevertheless, the low bimolecular rate constant of reaction with $\mathrm{O}_{2}$ does not confer high resistance towards $\mathrm{O}_{2}$. This suggests that the initial rate of reaction of $\mathrm{O}_{2}$ with the active site plays little role in the activity remaining after $\mathrm{O}_{2}$ departure, which is probably more a result of the reactivation kinetics. 


\section{Acknowledgments}

The authors acknowledge support from CNRS, Agence Nationale de la Recherche (grants ANR-14-CE05-0010, ANR-15-CE05-0020, ANR-17-CE11-002) and Région PACA. The project leading to this publication has received funding from Excellence Initiative of Aix-Marseille University - A*Midex, a French "Investissements d'Avenir" programme. MB, MM, CG, AB, CL, VF and SD are members of the French Bioinorganic Chemistry group (http://frenchbic.cnrs.fr). This work was supported by the Deutsche Forschungsgemeinschaft (DFG, German Research Foundation) under project grant DO 785/62 and under Germany's Excellence Strategy - EXC 2008/1 (UniSysCat) - 390540038. Gefördert durch die Deutsche Forschungsgemeinschaft (DFG) im Rahmen der Exzellenzstrategie des Bundes und der Länder

- EXC 2008/1 (UniSysCat) - 390540038.

\section{References}

[1] D.A. Kozhevnikova, E.A. Taranov, A.V. Lebedinsky, E.A. Bonch-Osmolovskaya, T.G. Sokolova, Hydrogenogenic and Sulfidogenic Growth of Thermococcus Archaea on Carbon Monoxide and Formate, Mikrobiologiia. 85 (2016) 381-392.

[2] Y.J. Kim, H.S. Lee, E.S. Kim, S.S. Bae, J.K. Lim, R. Matsumi, A.V. Lebedinsky, T.G. Sokolova, D.A. Kozhevnikova, S.-S. Cha, S.-J. Kim, K.K. Kwon, T. Imanaka, H. Atomi, E.A. Bonch-Osmolovskaya, J.-H. Lee, S.G. Kang, Formate-driven growth coupled with $\mathrm{H}_{2}$ production, Nature. 467 (2010) 352-355.

[3] J.K. Lim, F. Mayer, S.G. Kang, V. Muller, Energy conservation by oxidation of formate to carbon dioxide and hydrogen via a sodium ion current in a hyperthermophilic archaeon, Proceedings of the National Academy of Sciences. 111 (2014) 11497-11502.

[4] G.J. Schut, G.L. Lipscomb, D.M.N. Nguyen, R.M. Kelly, M.W.W. Adams, Heterologous Production of an Energy-Conserving Carbon Monoxide Dehydrogenase Complex in the Hyperthermophile Pyrococcus furiosus, Front. Microbiol. 7 (2016) 29.

[5] T.G. Sokolova, C. Jeanthon, N.A. Kostrikina, N.A. Chernyh, A.V. Lebedinsky, E. Stackebrandt, E.A. Bonch-Osmolovskaya, The first evidence of anaerobic CO oxidation coupled with $\mathrm{H}_{2}$ production by a hyperthermophilic archaeon isolated from a deep-sea hydrothermal vent, Extremophiles. 8 (2004) 317-323.

[6] P. Oger, T.G. Sokolova, D.A. Kozhevnikova, N.A. Chernyh, D.H. Bartlett, E.A. BonchOsmolovskaya, A.V. Lebedinsky, Complete genome sequence of the hyperthermophilic archaeon Thermococcus sp. strain AM4, capable of organotrophic growth and growth at the expense of hydrogenogenic or sulfidogenic oxidation of carbon monoxide, J. Bacteriol. 193 (2011) 7019-7020.

[7] M.-S. Kim, A.R. Choi, S.H. Lee, H.-C. Jung, S.S. Bae, T.-J. Yang, J.H. Jeon, J.K. Lim, H. Youn, T.W. Kim, H.S. Lee, S.G. Kang, A novel CO-responsive transcriptional regulator and enhanced $\mathrm{H}_{2}$ production by an engineered Thermococcus onnurineus NA1 strain, Appl. Environ. Microbiol. 81 (2015) 1708-1714.

[8] M. Inoue, I. Nakamoto, K. Omae, T. Oguro, H. Ogata, T. Yoshida, Y. Sako, Structural and Phylogenetic Diversity of Anaerobic Carbon-Monoxide Dehydrogenases, Front. Microbiol. 9 
(2018) 3353.

[9] Y. Kung, C.L. Drennan, A role for nickel-iron cofactors in biological carbon monoxide and carbon dioxide utilization, Curr. Opin. Chem. Biol. 15 (2011) 276-283.

[10] P.A. Lindahl, Implications of a Carboxylate-Bound C-Cluster Structure of Carbon Monoxide Dehydrogenase, Angewandte Chemie International Edition. 47 (2008) 4054-4056.

[11] H. Dobbek, V. Svetlitchnyi, L. Gremer, R. Huber, O. Meyer, Crystal structure of a carbon monoxide dehydrogenase reveals a [Ni-4Fe-5S] cluster, Science. 293 (2001) 1281-1285.

[12] E.C. Wittenborn, M. Merrouch, C. Ueda, L. Fradale, C. Léger, V. Fourmond, M.-E. Pandelia, S. Dementin, C.L. Drennan, Redox-dependent rearrangements of the NiFeS cluster of carbon monoxide dehydrogenase, Elife. 7 (2018). https://doi.org/10.7554/eLife.39451.

[13] R.L. Kerby, P.W. Ludden, G.P. Roberts, In vivo nickel insertion into the carbon monoxide dehydrogenase of Rhodospirillum rubrum: molecular and physiological characterization of cooCTJ, J. Bacteriol. 179 (1997) 2259-2266.

[14] J.-H. Jeoung, H. Dobbek, Carbon dioxide activation at the $\mathrm{Ni}, \mathrm{Fe}-\mathrm{cluster}$ of anaerobic carbon monoxide dehydrogenase, Science. 318 (2007) 1461-1464.

[15] L. Domnik, M. Merrouch, S. Goetzl, J.-H. Jeoung, C. Léger, S. Dementin, V. Fourmond, H. Dobbek, CODH-IV: A High-Efficiency CO-Scavenging CO Dehydrogenase with Resistance to $\mathrm{O}_{2}$, Angew. Chem. Int. Ed Engl. 56 (2017) 15466-15469.

[16] M. Rousset, Z. Dermoun, M. Chippaux, J.P. Bélaich, Marker exchange mutagenesis of the hydN genes in Desulfovibrio fructosovorans, Mol. Microbiol. 5 (1991) 1735-1740.

[17] F. Leroux, S. Dementin, B. Burlat, L. Cournac, A. Volbeda, S. Champ, L. Martin, B. Guigliarelli, P. Bertrand, J. Fontecilla-Camps, M. Rousset, C. Léger, Experimental approaches to kinetics of gas diffusion in hydrogenase, Proc. Natl. Acad. Sci. U. S. A. 105 (2008) 11188-11193.

[18] J. Hadj-Saïd, M.-E. Pandelia, C. Léger, V. Fourmond, S. Dementin, The Carbon Monoxide Dehydrogenase from Desulfovibrio vulgaris, Biochim. Biophys. Acta. 1847 (2015) 15741583.

[19] C. Fu, W.P. Donovan, O. Shikapwashya-Hasser, X. Ye, R.H. Cole, Hot Fusion: an efficient method to clone multiple DNA fragments as well as inverted repeats without ligase, PLoS One. 9 (2014) e115318.

[20] M. Merrouch, J. Hadj-Saïd, L. Domnik, H. Dobbek, C. Léger, S. Dementin, V. Fourmond, $\mathrm{O}_{2}$ Inhibition of Ni-Containing CO Dehydrogenase Is Partly Reversible, Chemistry. 21 (2015) 18934-18938.

[21] C. Léger, S. Dementin, P. Bertrand, M. Rousset, B. Guigliarelli, Inhibition and aerobic inactivation kinetics of Desulfovibrio fructosovorans NiFe hydrogenase studied by protein film voltammetry, J. Am. Chem. Soc. 126 (2004) 12162-12172.

[22] V. Fourmond, QSoas: A Versatile Software for Data Analysis, Anal. Chem. 88 (2016) 50505052.

[23] M. Merrouch, J. Hadj-Saïd, C. Léger, S. Dementin, V. Fourmond, Reliable estimation of the kinetic parameters of redox enzymes by taking into account mass transport towards rotating electrodes in protein film voltammetry experiments, Electrochim. Acta. 245 (2017) 1059-1064.

[24] U. Mueller, N. Darowski, M.R. Fuchs, R. Förster, M. Hellmig, K.S. Paithankar, S. Pühringer, M. Steffien, G. Zocher, M.S. Weiss, Facilities for macromolecular crystallography at the Helmholtz-Zentrum Berlin, J. Synchrotron Radiat. 19 (2012) 442-449.

[25] M. Krug, M.S. Weiss, U. Heinemann, U. Mueller, XDSAPP: a graphical user interface for the convenient processing of diffraction data usingXDS, Journal of Applied Crystallography. 45 (2012) 568-572.

[26] P. Adams, P. Afonine, N. Echols, J. Headd, R. Grosse-Kunstleve, N. Moriarty, New tools for structure refinement in PHENIX, Acta Crystallographica Section A Foundations of 
Crystallography. 66 (2010) s15-s15.

[27] P. Emsley, K. Cowtan, Coot: model-building tools for molecular graphics, Acta Crystallographica Section D Biological Crystallography. 60 (2004) 2126-2132.

[28] L. Pravda, D. Sehnal, D. Toušek, V. Navrátilová, V. Bazgier, K. Berka, R. Svobodová Vareková, J. Koca, M. Otyepka, MOLEonline: a web-based tool for analyzing channels, tunnels and pores (2018 update), Nucleic Acids Res. 46 (2018) W368-W373.

[29] E.F. Pettersen, T.D. Goddard, C.C. Huang, G.S. Couch, D.M. Greenblatt, E.C. Meng, T.E. Ferrin, UCSF Chimera--a visualization system for exploratory research and analysis, J. Comput. Chem. 25 (2004) 1605-1612.

[30] E.C. Wittenborn, S.E. Cohen, M. Merrouch, C. Léger, V. Fourmond, S. Dementin, C.L. Drennan, Structural insight into metallocofactor maturation in carbon monoxide dehydrogenase, J. Biol. Chem. 294 (2019) 13017-13026.

[31] M. Del Barrio, M. Sensi, C. Orain, C. Baffert, S. Dementin, V. Fourmond, C. Léger, Electrochemical Investigations of Hydrogenases and Other Enzymes That Produce and Use Solar Fuels, Acc. Chem. Res. 51 (2018) 769-777.

[32] V. Fourmond, E.S. Wiedner, W.J. Shaw, C. Léger, Understanding and Design of Bidirectional and Reversible Catalysts of Multielectron, Multistep Reactions, J. Am. Chem. Soc. 141 (2019) 11269-11285.

[33] C. Orain, L. Saujet, C. Gauquelin, P. Soucaille, I. Meynial-Salles, C. Baffert, V. Fourmond, $\mathrm{H}$. Bottin, C. Léger, Electrochemical Measurements of the Kinetics of Inhibition of Two FeFe Hydrogenases by $\mathrm{O}_{2}$ Demonstrate That the Reaction Is Partly Reversible, J. Am. Chem. Soc. 137 (2015) 12580-12587.

[34] C. Léger, P. Bertrand, Direct electrochemistry of redox enzymes as a tool for mechanistic studies, Chem. Rev. 108 (2008) 2379-2438.

[35] M. Benvenuti, Étude de la biodiversité des CO déshydrogénases à Nickel, PhD thesis, AixMarseille University, 2019.

[36] J.-H. Jeoung, T. Giese, M. Grünwald, H. Dobbek, Crystal structure of the ATP-dependent maturation factor of $\mathrm{Ni}, \mathrm{Fe}-$ containing carbon monoxide dehydrogenases, J. Mol. Biol. 396 (2010) 1165-1179.

[37] M. Merrouch, M. Benvenuti, M. Lorenzi, C. Léger, V. Fourmond, S. Dementin, Maturation of the [Ni-4Fe-4S] active site of carbon monoxide dehydrogenases, J. Biol. Inorg. Chem. 23 (2018) 613-620.

[38] T. Inoue, T. Yoshida, K. Wada, T. Daifuku, K. Fukuyama, Y. Sako, A simple, large-scale overexpression method of deriving carbon monoxide dehydrogenase II from thermophilic bacterium Carboxydothermus hydrogenoformans, Biosci. Biotechnol. Biochem. 75 (2011) 1392-1394.

[39] S.A. Ensign, Reactivity of carbon monoxide dehydrogenase from Rhodospirillum rubrum with carbon dioxide, carbonyl sulfide, and carbon disulfide, Biochemistry. 34 (1995) 53725378.

[40] A. Parkin, J. Seravalli, K.A. Vincent, S.W. Ragsdale, F.A. Armstrong, Rapid and efficient electrocatalytic $\mathrm{CO}_{2} / \mathrm{CO}$ interconversions by Carboxydothermus hydrogenoformans $\mathrm{CO}$ dehydrogenase I on an electrode, J. Am. Chem. Soc. 129 (2007) 10328-10329.

[41] O. Lazarus, T.W. Woolerton, A. Parkin, M.J. Lukey, E. Reisner, J. Seravalli, E. Pierce, S.W. Ragsdale, F. Sargent, F.A. Armstrong, Water-gas shift reaction catalyzed by redox enzymes on conducting graphite platelets, J. Am. Chem. Soc. 131 (2009) 14154-14155.

[42] J. Hadj-Saïd, La CO déshydrogénase de Desulfovibrio vulgaris, PhD thesis, Aix-Marseille University, 2015.

[43] V.C.-C. Wang, M. Can, E. Pierce, S.W. Ragsdale, F.A. Armstrong, A unified electrocatalytic description of the action of inhibitors of nickel carbon monoxide dehydrogenase, J. Am. Chem. Soc. 135 (2013) 2198-2206. 
